\title{
USING DIVERSITY INDICES FOR IDENTIFYING THE PRIORITY SITES FOR HERPETOFAUNA CONSERVATION IN THE DEMOCRATIC REPUBLIC OF THE CONGO
}

\author{
Kusamba Z. Chifundera ${ }^{1,2}$ \\ ${ }^{1}$ Research Center in Natural Sciences at Lwiro, Democratic Republic of the Congo \\ ${ }^{2}$ National Pedagogical University at Kinshasa, Democratic Republic of the Congo \\ e-mail:chifkusamba@gmail.com
}

Received: 31.03.2018. Revised: 25.03.2019. Accepted: 28.04.2019.

\begin{abstract}
To date, knowledge about the herpetological diversity and the species distribution in the Democratic Republic of the Congo remains largely incomplete. In order to fill this gap, we carried out long-term and large-scale herpetological surveys to improve the knowledge about the herpetofauna occurrence and species composition data. Site scanning, visual encounter, transect and quadrat methods were used along with call recordings for identifying and locating amphibians on each survey site. Additional data were gathered from literature reviews and museum collections. The herpetological diversity was assessed on twenty-eight survey sites located in both Congo Basin and Albertine Rift ecoregions. All surveyed localities and sites were georeferenced in order to generate distribution maps by using QGIS 2.14.0 software. Herpetological diversity indices were generated using the PAST software. Using morphological characters and information provided by DNA analysis, species lists were produced per site and on national level. The results show that the rich Congolese herpetofauna is composed of 605 species, including 247 (40.83\%) amphibians and 358 (59.17\%) reptiles. There are 57 endemic amphibian species (23.1\%) and of these, $19(32.7 \%)$ are located in Protected Areas. There are 38 endemic reptile species (10.6\%) and of these, twelve (31.5\%) are found in Protected Areas. Furthermore, there are nine and seventeen threatened amphibian and reptile species respectively; but only $20 \%$ of these have been detected inside of national parks. Concerning this situation, it appears that, if no action is undertaken for fighting against the human pressure on habitat, there will be a decline in populations and species in the Democratic Republic of the Congo. Based on relevant indices, including species richness, rarity, diversity, endemism, and presence of threatened species, and other objective criteria in respect to international standards, the following ten sites were identified as sites of priority for conservation: Marungu, Kabobo, Itombwe, Ituri, Tshopo, Mai Ndombe Tumba, Lualaba, Lukaya, Sankuru, and Ubangi Uele. These sites are proposed as new Protected Areas for reaching the government's national conservation targets of land preservation necessary for conserving the rich biodiversity.
\end{abstract}

Key words: amphibian and reptile surveys, Central Africa, endemic species, geographic distribution, Protected Area, species richness, threatened species

\section{Introduction}

Amphibians and reptiles are important components of biological diversity in the Democratic Republic of the Congo. They play a role in the ecosystem functions by maintaining the ecological processes and thus, require appropriate conservation measures (Chifundera \& Behangana, 2013; Valencia-Aguilar et al., 2013; Van Oudenhoven \& de Groot, 2013). The Congolese biodiversity is being lost more rapidly due to habitat loss and disturbance, specifically the commercial logging, mining, industrial agriculture and poaching (Chifundera, 2012; Greenbaum \& Chifundera, 2012; Zhuravleva et al., 2013). The driving forces for these human-induced threats consist of a complex web of economic, social, and political factors, which converge at local and national levels. Examples of these complex factors that encourage unsustainable exploitation of natural resources include population growth, severe and widespread poverty, inappropriate landuse systems, weak Protected Area management, and a lack of adequate governance policy (Mubalama, 2010). A range of solutions has been suggested to address both the immediate problems catalysed by anthropogenic activities and the root causes driving them. It is known worldwide that species are threatened with extinction due to human pressure (Speight, 1992; Hartley et al., 2007; Dirzo et al., 2014). According to the Convention on Biological Diversity (CBD), parties to this convention are urged to survey and conserve their biodiversity. The CBD was adopted in 1992 by the United Nations, and was ratified in December 1993 by the Democratic Republic of the Congo. There exist several national legal instruments including presidential decrees or ordinances, and governmental or provincial rules 
known as «Arrêtés or Décisions» for regulating all the conservation activities in the Democratic Republic of the Congo. The national legal instruments and ratified international conventions and agreements work towards the conservation of nature stating the obligations to safeguard the national biodiversity by creating and managing Protected Areas (Mbalanda, 2006). The Democratic Republic of the Congo has defined a National Biodiversity Strategy as framework for decision-making in order to increase the percentage of Protected Areas in the country from $11.07 \%$ in 2016 up to $15 \%$ by 2020 , as estimated by the Congolese Wildlife Authority which is called «Institut Congolais pour la Conservation de la Nature» and outlined by the World Database on Protected Areas (UNEP-WCMC, 2016). However, deciding to create new Protected Areas is a serious challenge because such a decision should be grounded by science -based information (Scott et al., 1987; Milian \& Rodary, 2010). Despite the existence of law No 14-003 and complementary regulations related to the nature conservation, the Congolese Wildlife Authority has failed to promote a framework in which scientists play a central role in the correct identification of priority sites for conservation. The aforementioned law was elaborated by the Congress and promulgated by the Head of State. It covers and regulates the procedures for creating and managing Protected Areas and holds the ban on poaching and habitat degradation. Moreover, it provides guidelines for protecting fauna, flora and microorganisms and encourages scientists to undertake research on the biological diversity in the Democratic Republic of the Congo in relation with the international instruments. In accordance with this law, our long-term and large-scale surveys show that Protected Area design policy should be framed by strong ecological baselines rather than simply conservation institutional factors.

Accordingly, this study pursues the following objectives: (1) to produce baseline diversity data for reptiles and amphibians, and (2) to determine the priority sites for conservation based on diversity indices. A Site of Priority for Conservation (SPC) is identified by using objective criteria in reference to international standards (Scott et al. 1987; Speight, 1992; Seymour et al., 2001). Accordingly, this study intends to respond to the need of allocating an ecological baseline to the Protected Area management in the Democratic Republic of the Congo.

\section{Material and Methods}

\section{Study area}

The surveys were carried out throughout the Democratic Republic of the Congo (2 345409 $\mathrm{km}^{2}, 82$ million inhabitants). The country is located in the heart of the African continent. We sampled 28 sites in aquatic and terrestrial ecosystems within ten phytogeographic territories already defined by Robyns (1948) and White (1981) whose characteristics and distribution are detailed in Table 1. In total, there is a constellation or set of 326 sampled localities (Fig. 1) grouped into 28 sites distributed into two ecoregions (Fig. 2): ten sites in the Albertine Rift and eighteen sites in the Congo Basin. The survey sites and sampling localities were georeferenced by using a GPS unit (Garmin GPSmap 62s). They were geospatially processed by QGIS-OSGeo4W -2.14.0-1 software ellipsoid UTM 35-DatumWGS84 for generating distribution map.

From a biogeographic point of view, a locality is a geographic unit from which a sample is located, a site is a set of several localities or stations. The network of survey sites is shown in Fig. 2.

\section{Historical records}

We compiled data from the literature and the museum collections covering the period from 1920 to 2014 with reference to the most important works produced by scientists who were deeply involved in Congolese herpetology, especially Laurent (1956, 1965, 1972, 1973, 1982, 1983), De Witte (1962, 1965, 1966), Bourgeois (1968), Heymans (1982), Schmidt \& Noble (1998), Behangana et al. (2009), and Greenbaum (2017). For more consistency, we used the results from our bibliographical study made under the auspices of UNESCO-MAB (Chifundera, 2009). Data extracted from the archives show that the difference in numbers of previous known species represent differences in sampling effort, not in actual species diversity. This hypothesis was tested by the results obtained from the bibliographical study showing that the surveys were focused only on the Protected Areas creating an imbalance in the survey efforts. Most of the collections made before 1960 are from the Albertine Rift (86\%). A few specimens were collected from the western zone (Bandundu, Kinshasa, Lukaya and Lower Congo, 9\%), the central Congo Basin (3\%), and from other areas $(2 \%)$. In order to reduce the imbalance between the two ecoregions, survey efforts were increased in the Congo Basin. 
Before the Congolese Independence Day, June 1960, there were few herpetologists studying the Congolese herpetofauna. But at present, there are more than twelve scientists (nationals and internationals) involved in the fieldwork covering the whole country. In total, there are ca 300000 voucher specimens, including 250326 amphibian and 43724 reptile specimens. These impressive collections are not sufficiently documented because old voucher specimens were preserved in formalin being unsuitable for manipulations. We made a selection and by putting together old and our contemporary specimens, we got a study sample of $77365(25.78 \%)$ including $63841 \mathrm{am}-$ phibians $(82.52 \%)$ and 13524 reptiles $(17.48 \%)$. Moreover, there are 4000 tissues for DNA analysis and a collection of 120000 photos (Chifundera, 2009, 2014). The majority of these collections are kept at the Royal Museum for Central
Africa (Tervuren), the Royal Institute of Natural Sciences of Belgium, the University of Texas at El Paso (USA) and at the Centre de Recherche en Sciences Naturelles (CRSN) at Lwiro, Democratic Republic of the Congo. It is important to highlight that the high number of specimens from any survey site does not necessarily represent a high diversity. But our large data set facilitates the discrimination between species and sites, and the extensive coverage of the data set also ensures a distinction of the herpetofauna's biogeographical zones into two distinct ecoregions found in the Democratic Republic of the Congo, the Congo Basin and the Albertine Rift. The species lists that are produced from the historical data were updated following the current taxonomy according to Uetz (2010), Pyron et al. (2013), and Uetz \& Hošek (2018) for reptiles and Frost (2018) for amphibians.

Table 1. Distribution of survey sites in different phytogeographic territories in the Democratic Republic of the Congo

\begin{tabular}{|c|c|}
\hline Botanical domains & Survey sites \\
\hline \multicolumn{2}{|l|}{ A) The Guinean Province including six phytogeographic territories } \\
\hline $\begin{array}{l}\text { A1. The coastal territory covering the areas of Boma and Moanda, including the Mangroves along the Atlantic } \\
\text { Ocean. It is characterised by a long dry season (six months), and by savannah composed by xerophytes } \\
\text { vegetation and mangroves of mangles. This is an instable territory due to severe dryness. }\end{array}$ & Mangroves \\
\hline $\begin{array}{l}\text { A2. The Mayombe territory includes the Luki - Tshela landscape covered by a fragmented forest due to } \\
\text { anthropogenic activities. This is a secondary forest-savannah complex. The wildlife is in continuous decline } \\
\text { due to overconsumption of bushmeat. There is need of urgent protection measures. }\end{array}$ & Mayombe forest \\
\hline $\begin{array}{l}\text { A3. The Lower Congo territory extending on the Lukaya - Kasangulu-Matadi landscape and characterised } \\
\text { by dry savannah degraded by erosion. }\end{array}$ & Lukaya \\
\hline $\begin{array}{l}\text { A4. The Kasai - Kwango territory includes the Kinshasa hinterland, Kwilu and Western Kasai zones. It } \\
\text { is covered by the Guinean savannah, which receives constant rainfalls in the major part of the year. This } \\
\text { landscape is threatened by mine extraction, which is destroying the natural habitats leading to remarkable } \\
\text { environment changes. }\end{array}$ & $\begin{array}{l}\text { Kasai, Kwango, Kinshasa } \\
\text { Malebo }\end{array}$ \\
\hline $\begin{array}{l}\text { A5. The Lualaba - Lower Katanga forms the ark Pangi-Kolwezi - Likasi - Lubumbashi, and it is covered } \\
\text { by herbaceous savannah and relic forests submitted to severe dryness and mine extraction. Gallery-forest } \\
\text { patches are observed along the rivers. }\end{array}$ & Lualaba and Kasai \\
\hline $\begin{array}{l}\text { A6. The Central Congo Basin territory covers Mai Ndombe-Equateur-Salonga-Sankuru-Tshopo-Maiko } \\
\text { - Ituri. This is an intact area, which is not degraded, less explored, covered by typical tropical rainforest, } \\
\text { which is still ombrophilic, humid, and evergreen and virgin. The presence of peat bogs is responsible for the } \\
\text { carbon sequestration that attracts the international community because of the large amount of absorbed } \mathrm{CO}_{2} \text {. }\end{array}$ & $\begin{array}{l}\text { Salonga, Equateur, Mai } \\
\text { Ndombe Tumba, Maiko, } \\
\text { Lomami, Tshopo, Congo } \\
\text { River riparian zones, } \\
\text { Sankuru, Ituri forest, and } \\
\text { Epulu }\end{array}$ \\
\hline $\begin{array}{l}\text { A7. The territory of Ubangi-Uele extending on the Libenge - Mahagi areas and characterised by a long rainy } \\
\text { season lasting nine months, and covered by park-savannah composed by Sudano-Guinean elements. }\end{array}$ & Ubangi-Uele and Garamba \\
\hline \multicolumn{2}{|l|}{ B) The Eastern Province } \\
\hline $\begin{array}{l}\text { B8. The territory of Lake Albert covers the Blue Mountains and the Lendu Plateau. It is characterised by } \\
\text { eastern xerophytes elements. The valleys contain a dry savannah and mountains, and they are covered by } \\
\text { typical montane forests. }\end{array}$ & Lendu Plateau \\
\hline $\begin{array}{l}\text { B9. The territory of lakes Edward and Kivu stretching the Ruwenzori massif, Virunga - Kahuzi-Biega - } \\
\text { Ruzizi - Tanganyika - Itombwe landscape with several habitat types with dry plains sometimes covered by } \\
\text { lava from volcanic eruptions. }\end{array}$ & $\begin{array}{l}\text { Virunga, Kahuzi-Biega, } \\
\text { Kivu, Ruzizi, Tanganyika } \\
\text { and Itombwe }\end{array}$ \\
\hline \multicolumn{2}{|l|}{ C) The Zambezian Province } \\
\hline $\begin{array}{l}\text { C10. The Upper Katanga extends on the Kabobo - Marungu - Upemba landscape with the Zambezian flora } \\
\text { with southern savannah and gallery-forests. The main characteristic is the presence of the dry Miombo forest } \\
\text { composed of Brachystegia and Isoberlina vegetation growing on a degraded plateau, influenced by long dry } \\
\text { season lasting seven months. }\end{array}$ & $\begin{array}{l}\text { Upemba, Kundelungu, } \\
\text { Kabobo, and Marungu }\end{array}$ \\
\hline
\end{tabular}




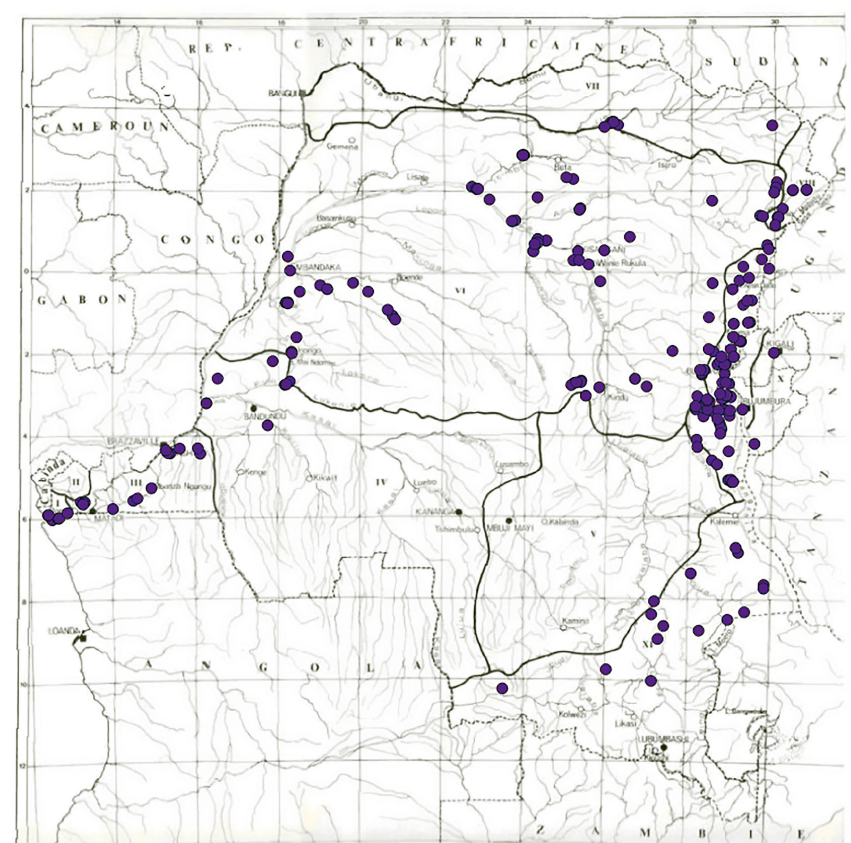

Fig. 1. Distribution of herpetological sampling localities in the Democratic Republic of the Congo (spheres represent georeferenced localities).

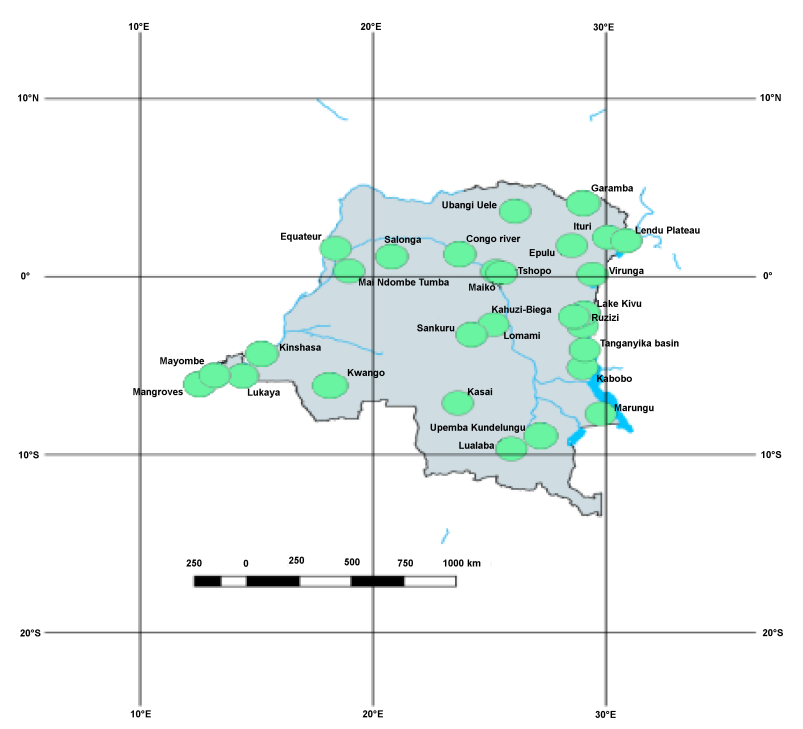

Fig. 2. Geographic position of herpetological survey sites in the Democratic Republic of the Congo (green spheres represent the survey sites).

Contemporary records obtained by prospective or inductive methods

The information is based on results from an ongoing survey project developed since 2008 in collaboration with different partner institutions in the Democratic Republic of the Congo as well as European and American research institutions. It also includes information from recent studies and reports on amphibian and reptile fauna in the Albertine Rift and the Congo Basin (Behangana et al., 2009; Chifundera \& Behangana, 2013; Chifundera et al., 2014). Prospective method consisted of con- ducting fieldwork on sites according to the vegetation cover and the altitudinal gradients, and chosen sites are located in each of the ten phytogeographic territories ensuring that the site-based sampling covers habitat features inside and outside Protected Areas (Dodd, 2010, 2016). However, for logistical reasons, e.g. lack of roads, dugout canoes, and bad weather, unrest and remoteness were limiting factors for reaching some of the survey sites.

We used opportunistic site scanning, visual encounter, call recording, transect, and quadrat methods for surveying reptiles and amphibians in aquatic and terrestrial ecosystems (Heyer et al., 1994; Eeckout, 2010; Nagy et al., 2013; Dodd, 2010, 2016). The transect $\left(2 \mathrm{~m} \times 500 \mathrm{~m}=1000 \mathrm{~m}^{2}\right)$ is placed and oriented to cross all the landscape features, e.g. river, slope, hill, valley, savannah, shrub, pristine forest, degraded habitat, and mosaics. We used $5 \mathrm{~m} \times 5 \mathrm{~m}$ for searching individuals of burrowing species (Caecilians, Amphisbaenians) in the litter. On each site we surveyed each transect or quadrat twice before moving to another site. We conducted the fieldworks during daylight as well as during the night. The work during daylight consisted of crossing a chosen site between 9:00 a.m. and 1:00 p.m., exploring streams, rivers, ponds, beaches, holes, dead tree trunks, turning back the leaf litter, and checking the canopy. Some lizards, crocodiles and snakes are usually seen basking in the sun. Night-time work was performed from 6:00 to 10:00 p.m., searching amphibians by using headlamps. Surveys were carried out twice a year, during the dry and rainy seasons. Opportunistic site scanning consists of walks for searching and catching any individual seen in the area. Encountered individuals were hand-captured, but in some cases, we used a net for catching aquatic individuals and a gripper was used for catching snakes. Captured amphibian individuals were euthanised by using MS222, and T61 was used for killing reptiles. The specimens were fixed in a $10 \%$ formalin solution, and after 24 hours, they were rinsed with tap water and then preserved in a $70 \%$ ethanol. Where the identification is difficult, the euthanised animal is photographed, and a small tissue $\left(1 \mathrm{~mm}^{3}\right)$ is collected from the muscle of the thigh or tongue and was preserved in a $2 \mathrm{ml}$ vial containing $95 \%$ ethanol. DNA analyses are carried out in the Molecular Unit of the Department of Biological Sciences, University of Texas at El Paso (USA) with the support of E. Greenbaum, Director of the UTEP Biodiversity Collections. Furthermore, we used the available barcoding database to identify reptile 
species because half of the number of known reptile species from the Democratic Republic of the Congo are already barcoded (Matthyssen, 2014; Nagy et al., 2013; Nagy, 2014). Amphibian chorus was recorded by a sound recorder apparatus (Fischer Scientific Co) and were helpful for identifying the species, and for detecting and locating individuals. We have observed that amphibians produce a maximum of calls in some range of humidity $(70 \%)$ and of temperature $\left(20-25^{\circ} \mathrm{C}\right)$. Accordingly, for recording humidity and temperature levels we used a digital thermo hygrometer manufactured as compact unit by Fischer Scientific Co. An analysis of recorded sounds produced specific characteristics used for distinguishing species within frog and toad communities. We used this method for studying Xenopus and Leptopelis species, but due to the aim of this work, we did not show the sonogram analysis. However, sonograms are shown in Evans et al. (2011), Roelke et al. (2011). A powerful spotlight was used to detect the presence of crocodile individuals. Moreover, vegetation cover, hydrographic system, and anthropogenic activities were recorded. In all cases, a tag was attached to each voucher specimen with the following inscriptions: date, names of the collector, ID number of the specimen, and locality with coordinates. For further taxonomic and biogeographical studies, voucher specimens are kept in the Zoology $\mathrm{Mu}-$ seums in the Democratic Republic of the Congo, USA and Europe. Campaigns in villages and collaboration with local communities are helpful for collecting more specimens in a short time. Thus, during the campaigns, information about the traditional knowledge and community uses of herpetofauna was recorded (Chifundera \& Malasi, 1989; Chifundera, 1990). The analysis of our datasets afforded to obtain data on: (1) the georeferenced survey sites, (2) the species lists per site and on national levels; (3) the species conservation status drawn from the IUCN's Global Amphibian and Reptile Assessment Working Groups (Baillie et al., 2004; IUCN, 2017), and (4) the sites of priority for conserving the amphibian and reptile species in the Democratic Republic of the Congo.

\section{Sampling and taxonomic considerations}

Presence-only data from museum, and literature records were used (Gormley et al., 2011; Dodd, 2018), and they were consolidated by field records based on incidental sightings in a way that accounts from known sampling design. Prior to the study, we made a complete bibliographical analy- sis on the Congolese herpetology, and the results showed areas where few or no specimens were recorded (Chifundera, 2009). We observed some striking contrasts in distribution of specimen records. In fact, the contrasts in quantity and quality of data from the Albertine and the Congo basin illustrate the biodiversity knowledge inequality between the two ecoregions (Chifundera, 2009), and based on these findings we identified the gaps in the previous studies. It appeared that there is a big dark hole in the Congo Basin (Chifundera et al., 2014) and other researchers reached the same conclusion (Kielgast \& Lötters, 2011; Tolley et al., 2016). We developed considerable efforts to reduce the imbalance by performing the following techniques: (1) intensification of searches in the unexplored areas of the Congo Basin by increasing the number of the survey sites from ten to eighteen; (2) areas located inside and outside of the Protected Areas were surveyed; (3) the research team was also expanded by involving international collaborators from the USA, Belgium, Denmark, South Africa, Uganda, the Czech Republic, Congo Brazzaville and Uganda (Greenbaum, 2017). Species distribution was compared to that produced by the TDWG (2017) which is also used by the IUCN specialist groups for reptiles and amphibians. In most of the cases the distribution maps were identical for well- known species but were different for newly discovered species such as Cardioglossa congolia Hirschrch, Blackburn, Greenbaum, 2014, Kinyongia gyrolepis Greenbaum, Tolley, Joma \& Kusamba, 2012, Xenopus lenduensis Evans, Greenbaum, Kusamba, Carter, Tobias, Mendel \& Kelley, 2011 and Trachylepis makolowodei Chirio, Ineich, Schmitz \& Lebreton, 2008 or Cordylus marunguensis Greenbaum, Stanley, Kusamba, Moninga, Goldberg \& Bursey, 2012. In order to update the taxonomic data, we tracked the species names through specialised websites, such as: AmphibiaWeb (http://amphibiaweb.org/cgi/amphib_query), the Amphibian Species of the World (Frost, 2018), and the Reptile Database (Uetz \& Hošek, 2018). We also used taxonomic rearrangements made by several specialists in herpetological taxonomy (Thys van Den Audaenerde, 1963a,b; Roux-Estève, 1974; Townsend et al., 2004; Vidal \& Hedges, 2005; Hedges, 2014). Moreover, as Operational Taxonomic Units (OTU) are recognised globally (Sokal \& Sneath, 1963; Blaxter et al., 2005; Cheng et al., 2013), we paid particular attention to all of them, and they were published by our teams as distinct lineages on which further 
ongoing taxonomic studies were undertaken and have already afforded new species (Larson et al., 2016; Hughes et al., 2017; Broadley et al., 2018; Greenbaum et al., 2018; Hughes et al., 2018; Portillo et al., 2018; Wüster et al., 2018). This work is produced based on long-term and large-scale surveys. But, despite the uncertainties associated with uneven sampling effort, we project that the results are sufficiently robust to support findings that meet the study goals.

\section{Measuring species richness and diversity}

Based on the number of species and individual counts (relative abundances), we calculated indices for measuring species diversity (Dodd, 2010, 2016; Magurran \& McGill, 2011; Gutiérrez-Hernández et al., 2017). Data were computed and indices were automatically generated using PAST 3.24 software (Hammer et al., 2001). Details about the methods and procedures used for measuring the diversity indices are presented below according to Sutherland, 2000, 1996; Brugière, 2012; Jenkins et al., 2013; Seymour et al., 2001; Stuart et al., 2004; Scott et al., 1987.

The species richness index represents the number of species composing the herpetofaunal assemblage on each survey site. Based on percentage quartiles, any site harbouring $25 \%$ of amphibian (62) and reptile (98) species, has a high species richness value.

The diversity index is expressed as Shannon's index of diversity, and is calculated by taking into account the species richness (S) and individual counts $(\mathrm{N})$ following the formula given below:

$H=\sum_{i=1}^{S}-\left(P_{i} \ln P_{i}\right)$ or $H^{\prime}=-\sum_{i=1}^{S}(n i / N) \ln (n i / N)$,

where $\mathrm{H}=$ the Shannon's diversity index; $\mathrm{P}_{\mathrm{i}}=$ fraction of the entire population made up of species $\mathrm{i} ; \mathrm{S}=$ numbers of species identified in the sample; $\sum=$ sum from species 1 to species $S ; \ln =$ natural logarithm.

To calculate the Shannon's diversity index, we divided the number of individuals of the first species found in the sample by the total number of individuals of all species $(\mathrm{ni} / \mathrm{N})$. We obtain $\mathrm{P}_{\mathrm{i}}$ multiply the fraction by its natural $\log \left(\mathrm{P}_{1} \times \ln \mathrm{P}_{1}\right)$ and the operation is repeated for all of the different species composing the sample. The total of species is represented by « $\mathrm{S}$ ». The sum of all $\left(\mathrm{P}_{\mathrm{i}} \times \ln \mathrm{P}_{\mathrm{i}}\right)$ products generates the value of $\mathrm{H}^{\prime}$, which is known as Shannon's index or Shannon-Wiener index. It is constrained between 0 and 5, so that the greater value of 4 , the great diversity (Magurran \& Mc-
Gill, 2011). To check, if the herpetological communities are composed by the same species, we used the Simpson's $(1-D)$ which is the measure of equitability or evenness $(\mathrm{J})$ constrained between 0 and 1 . The high value close to 1 (more than 0.5 ) indicates high diversity. It is calculated as follows:

$$
D=1-\left(\frac{\sum n(n-1)}{N(N-1)},\right.
$$

where $\mathrm{n}$ represents the total number of individuals of a particular species, and $\mathrm{N}$ is the total number of individuals of all species. We examined the dissimilarity between sites by using the Bray-Curtis index, which makes it possible to detect similar sites that are placed side by side on the cluster dendrogram (Bray \& Curtis, 1957). The index is bounded between 0 and 1 . When the index is below 0.5 , the sites are of similar composition; and when it is over 0.5 , the dissimilarity is high.

The rarity index is a measure of rarity at the community level by integrating the species distribution patterns in function of the rarity cut-off or threshold, which is always defined in relation with the maximum occurrence of widespread species. According to Leroy et al. (2013), we used the computed formula:

$$
I_{R R}=\frac{\sum_{i=1}^{S} w_{i}}{w_{\max }-w_{\min }},
$$

where $W_{1}$ is the weight of the $i^{\text {th }}$ species in the community (the term «weight» means the total number of occurrences). Once rarity weights have been assigned to each species, the index of rarity of an assemblage of species is calculated as the sum of the weights of the assemblage's species, which is divided by the assemblage's richness, and then normalised between 0 and 1 . However, the simplest method for calculating the rarity index is as follows:

$$
I=\sum k / A,
$$

where $\mathrm{k}$ is the number of sites, where the $\mathrm{i}^{\text {th }}$ species is found. And A is the total numbers of sites. The values are subdivided into quartiles determining the ranking classes of distribution (Sutherland, 2000; Magurran \& McGill, 2011): 1-25\% (present in 1-7 sites): rare species; $26-50 \%$ (present in 8-14 sites): occasional species; $51-75 \%$ (present in 15-21 sites: common species; 76-100\% (present in 22-28 sites): widespread species. Rare species are of special conservation concern.

Endemicity. An endemic species is defined as restricted range species. We only consider species 
that are endemic to the Democratic Republic of the Congo (national or country endemics).

Conservation status (CS). As indicated on the IUCN Red Lists (www.iucn.redlist.org/), threatened species include Vulnerable (VU), Endangered (EN), and Critically Endangered (CR). They are of special conservation concern.

The irreplaceability index (Ir) is calculated by using the formula given by Hartley et al. (2007) as modified by Brugière (2012):

$$
I r=\sum_{i=1}^{S}(1 \times R L s c) / t_{i}
$$

where $\mathrm{Ir}$ - irreplaceability index, $\mathrm{t}_{i}$ - number of sites where the species $i^{\text {th }}$ is present, $\mathrm{S}$ - total numbers of species composing the community dataset, and RLsc - the score of the conservation status of the $i^{\text {th }}$ species: $\mathrm{LC}=1, \mathrm{DD}=2, \mathrm{VU}=3$, $\mathrm{EN}=4, \mathrm{CR}=5$. The score varies between 1 and 5 , and a high value (3-5) indicates a significant site conservation value.

The naturalness indicator is used for estimating the site naturalness index, known as «naturalness indicator value» (NIV) used with reference to Németh-Seregélyes naturalness procedure. The NIV is compatible with the European systems taking into account the naturalness-based site quality index and derived from the vegetation cover (Németh \& Seregélyes, 1989; Molnár et al., 2007). Thus, the sites naturalness is defined by the habitat integrity level indicating a site out of human disturbance (Chifundera, 2012; Kovář, 2012; Erdős et al., 2017). The following ranking classes are recognised globally: 1 - totally degraded site; 2 - heavily degraded site; 3 - moderately degraded site; 4 semi-natural site; 5 - natural site.

Natural vegetation-based information was gathered from vegetation cover maps generated by satellite observations in the Democratic Republic of the Congo and already analysed by Zhuravleva et al. (2010). In this study, we only consider natural sites with value 5 .

Complementarity species. At least one charismatic or flagship species of another taxonomic group should be present on the site. The following complementary species are considered: Gorilla beringei Matschie, 1903, Pan paniscus Schwarz, 1929, Pan troglodytes Blumenbach, 1797, Okapia johnstoni Sclater, 1901, Loxodonta cyclotis (Blumenbach, 1797), Afropavo congensis Chapin, 1936, Trichechus senegalensis Link, 1795, Hippopotamus amphibius Linnaeus, 1758, Panthera leo (Linnaeus, 1758),
Panthera pardus Linnaeus, 1758, Ceratotherium simum cottoni Lydekker, 1908 and Phodilus prigoginei Schouteden, 1952.

Potential conservation values. As depicted by Smith et al. (1986), the site should respond to some of the following requirements: typicalness, educational value, cultural, policy, and funding possibilities that are essentials for habitat improvement, and recovery by natural change or appropriate management. Accordingly, a site with less human-park conflict, a requirement for attracting stakeholders including local community organisations, governmental institutions and funding agencies, has potentials for conserving species and habitats (Mubalama \& Chifundera, 1999; Vitule et al., 2012). It ranks from 0 to 5, with 0 - doesn't respond, 1 - responds to one requirement, 2 - responds to two requirements, 3 - responds to three conditions, 4 - responds to four requirements, and 5 - fulfill all the requirements. We consider the site responding to all of these requirements.

\section{Data treatment and analysis}

For analysing the community diversity and equitability, we used the Shannon's and Simpson's indices based on number of species and individual records of occurrence. Moreover, the Bray-Curtis index was used for comparison between sites, and similar sites were grouped into clusters that were visualised in the ordination graphics or cluster dendrograms (Bloom, 1981; Somerfield, 2008; Yoshioka, 2008). We did not use rarefaction curves because they may be limited by rare species (Dodd, 2010, 2016). But we only used classical survey methods performed globally in herpetological surveys (Heyer et al., 1994; Sutherland, 2000; Dodd, 2010, 2016; Greenbaum \& Chifundera, 2012). Based on the aforementioned methods, we produced species lists per site and country, including rare, endemic, and threatened species that are of special conservation concern. To avoid the weight of more or less abundant species within individual counts we used the «transform» application allowed by the PAST 3.24 software to transform the counts into presence-absence records. U1timately, herpetological diversity indices were generated and results attempt to achieve the research aim, which consists of determining the priority sites for the conservation of amphibian and reptile species in the Democratic Republic of the Congo. 


\section{Results}

Species richness and site species lists

Combining historical and contemporary data from 28 survey sites (Fig. 2) almost 605 species composing the Congolese herpetofauna were identified, including 247 (41.6\%) amphibian and 358 (58.4\%) reptile species (Electronic Supplement 1; Electronic Supplement 2). The present species lists were updated following taxonomic changes produced by several authors, such as Thomson et al. (2018), Pyron et al. (2013), and Broadley et al. (2018). The species numbers vary from a site to another (Fig. 3, Fig. 4; Electronic Supplement 1; Electronic Supplement 2). The species number at each site provides useful information about those sites, which harbour a high species richness index. For ranking the sites, we use a threshold of $25 \%$. Thus, a site harbouring 62 amphibian or 89 reptile species is qualified as a «site of high species richness index». There are eleven sites that do not respond to this criterion for the amphibian communities (Fig. 3), and for the reptile communities eight sites do not (Fig. 4).

The herpetological diversity in the Democratic Republic of the Congo

Herpetological diversity indices were calculated to reveal the most diverse sites (Table 2). About the amphibian assemblages, the indices of diversity are constrained between 3.296 and 4.8. The most diverse amphibian assemblages of which the index of diversity are higher than 4 , are located on the following sites: Upemba Kundelungu, Kahuzi-Biega, Virunga, Lake Kivu basin, Garamba and Epulu. The sites with lower amphibian diversity indices (values less than 4) are Lendu Plateau, Marungu, and Lomami. The Simpson's 1-D and the equitability (J) indices show that the species are equitably distributed into amphibian assemblages on the sites as ascertained by high values approaching 1 .

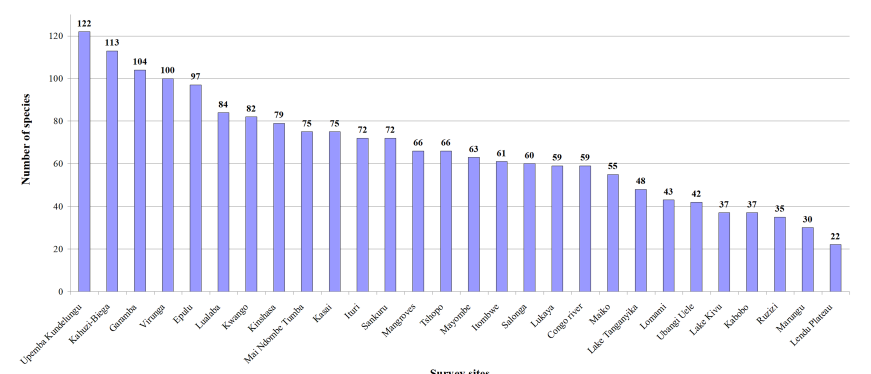

Fig. 3. Distribution of amphibian species per survey site (numbered tag represents the species number on the site).
The dissimilarity between the survey sites is revealed by the Bray-Curtis index, which is constrained between 0.28 and 0.92 as shown in the cluster dendrograms constructed, based on amphibian assemblages. The similar sites aggregate as visualised in Fig. 5. They form two distinct clusters: a group (0.4-0.88) formed by the site belonging to the Albertine Rift and another group (0.4-0.88) of sites located in the Congo Basin.

As far as the reptile communities concerned, we have observed that the Shannon's diversity indices are constrained between 3.296 and 4.804, and sites with value approaching 5 , harbour a high reptile diversity. The most diverse reptile communities are characterised by the index of diversity equal or superior to 4 , and are found on the following sites (Table 3): Upemba Kundelungu, Kahuzi-Biega, Virunga, Garamba and Epulu. The sites with weak index of diversity, inferior to 4 , are located on the following sites: Lendu Plateau, Marungu, and Ruzizi.

Furthermore, and based on the reptile assemblages, the dissimilarity index which is constrained between 0.05 and 0.85 shows evident differences between sites as visualised in the cluster dendrogram (Fig. 6) according to the Bray-Curtis distance index. In fact, we have observed in the cluster dendrogram two distinct site aggregates: the first is composed of one site (Kahuzi-Biega) and the second is formed by 27 sites. However, the second site aggregate is subdivided into a subgroup of sites belonging to the Albertine Rift, and another subgroup of sites located in the Congo Basin. And it includes six similar sites (Mangroves, Mayombe, Lukaya, Kinshasa, Kwango, and Mai Ndombe) located in the west and southwestern area of the country. They form a distinct aggregate. Another six similar sites are located in the heart of Congo Basin (Salonga, River Congo, Tshopo, Maiko, Sankuru, and Epulu). And a third group is composed of five similar sites (Ubangi Uele, Ituri, Garamba, Lualaba, and Kasai), located on the peripheries of the Congo Basin.

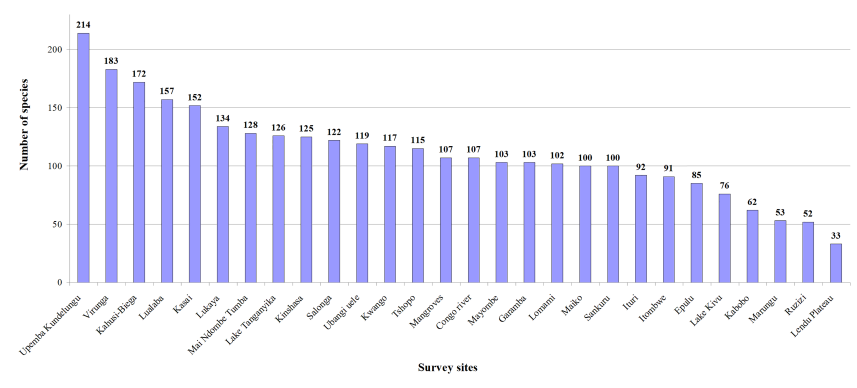

Fig. 4. Distribution of reptile species per survey site (numbered tag represents the species number on the site). 
Table 2. Distribution of amphibian diversity indices on sites

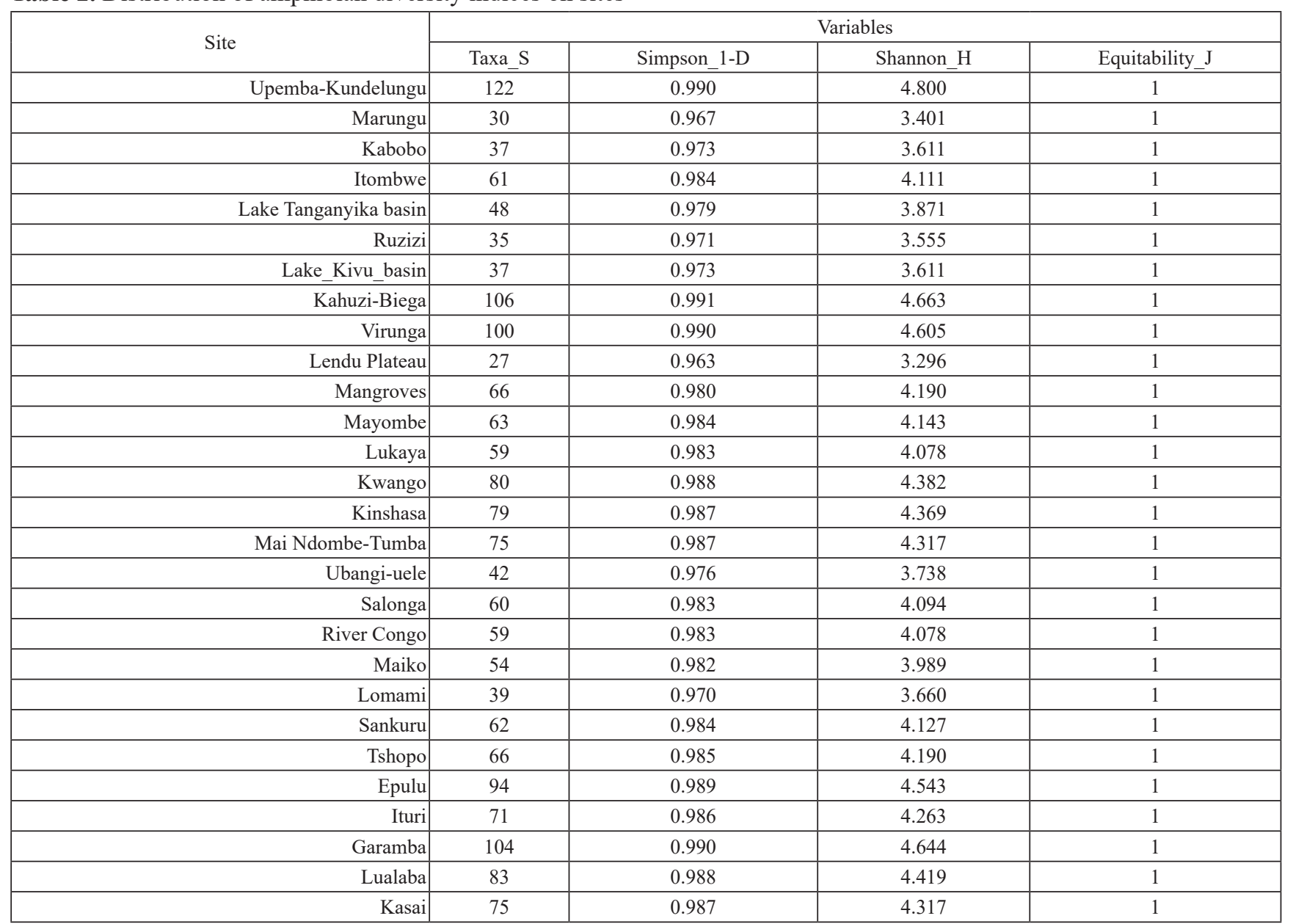

Similarity

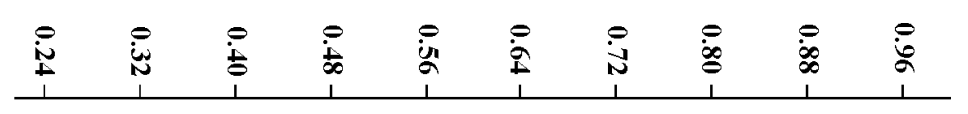

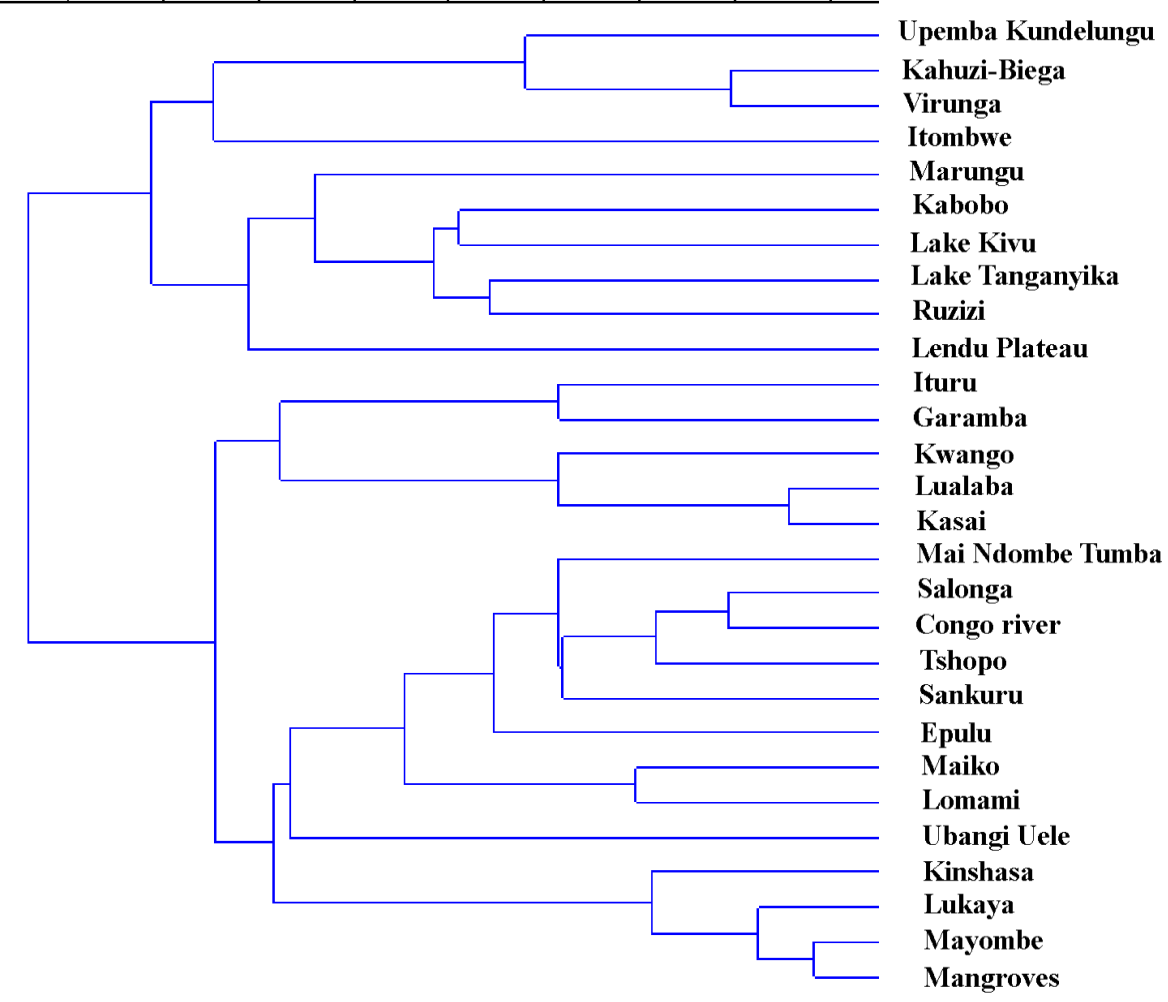

Fig. 5. Bray-Curtis's amphibian cluster dendrogram showing the level of similarity among sites. 
Table 3. Distribution of reptile diversity indices throughout the sites

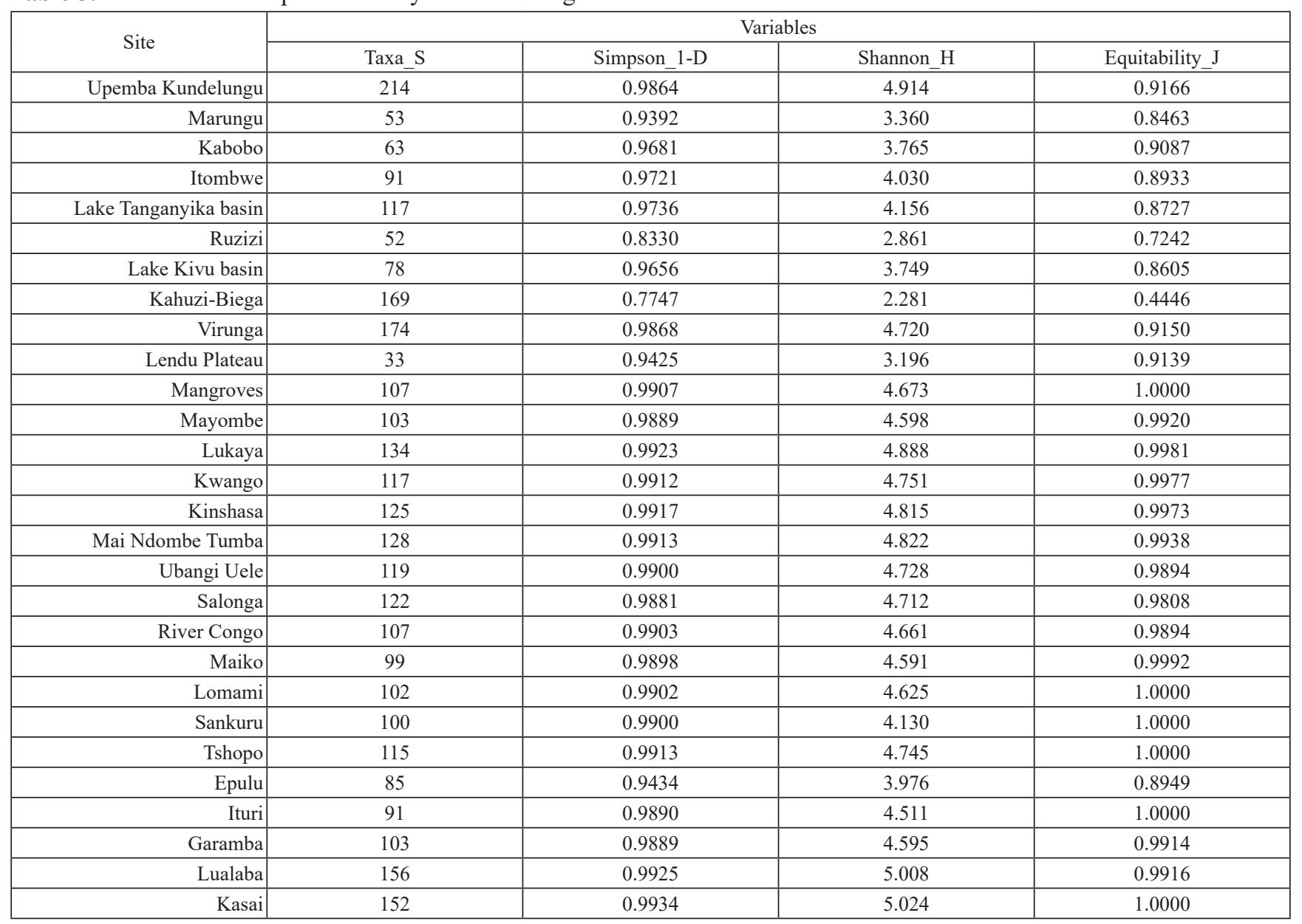

\begin{tabular}{|c|c|c|c|c|c|c|c|c|}
\hline \multicolumn{9}{|c|}{ Similarity } \\
\hline$\stackrel{\ominus}{\circ}$ & $\dot{n}$ & $\underset{i}{\stackrel{i}{i}}$ & 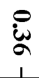 & $\stackrel{+}{\infty}$ & $\stackrel{\dot{\theta}}{\dot{\theta}}$ & 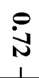 & $\stackrel{\infty}{+}$ & : \\
\hline
\end{tabular}

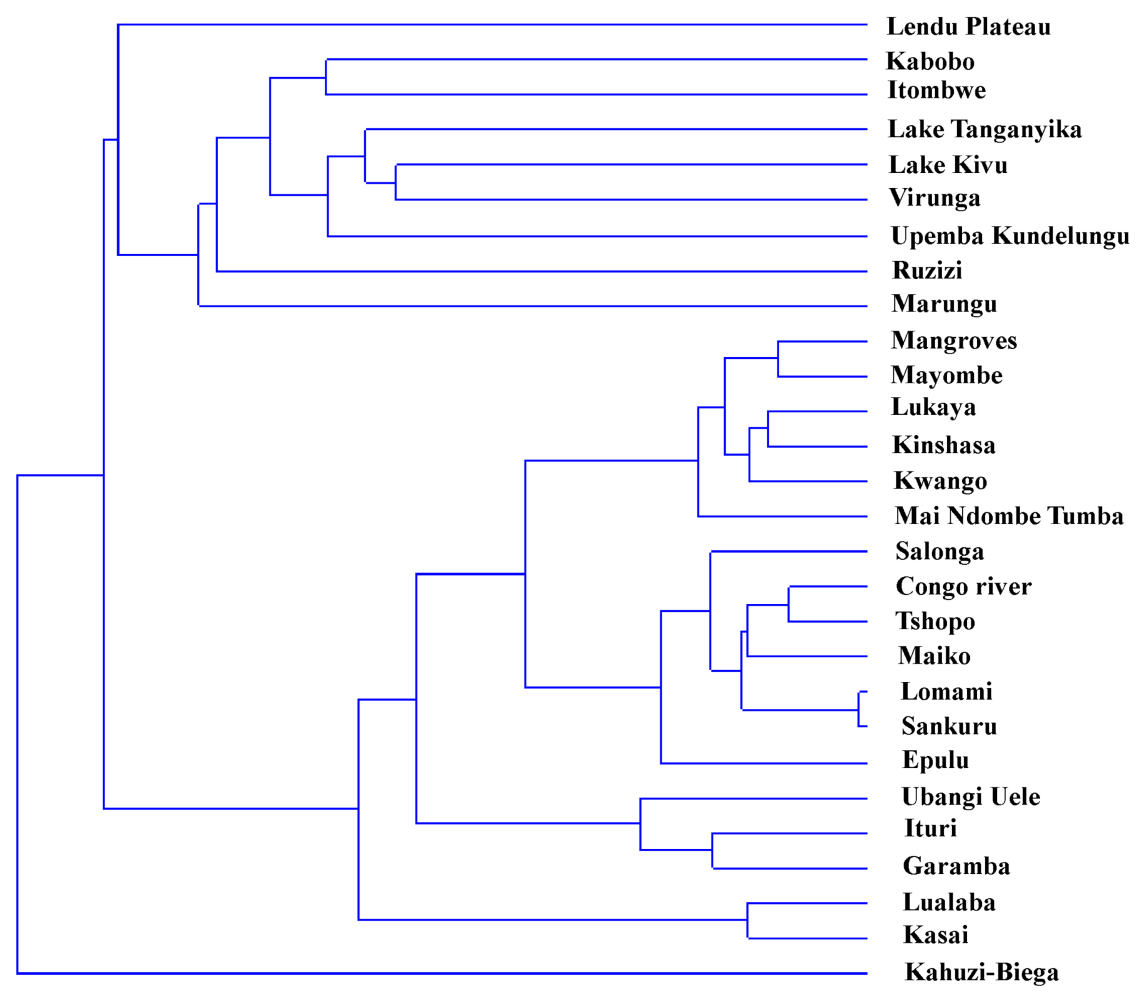

Fig. 6. Bray-Curtis's reptile cluster dendrogram showing the similarity among the study sites. 
Country endemic amphibian species and their conservation status

There are 57 endemic amphibian species (23.5\% of the total amphibian species known from DR Congo), but only $19(32.7 \%)$ of them are present under active protection of national parks (Table 4). However, over 51 amphibian species are listed on the IUCN Red Lists, nine (17\%) are recognised as threatened species, and the others are DD (39), LC (6) or NE (6). Among the threatened species, only one of them, Hyperolius polystictus, VU, is found in Kundelungu National Park. Most of the country's endemic amphibian species are located on the following sites: Upemba Kundelungu (14), Kahuzi-Biega (13), Virunga (11), Itombwe (10), Epulu (10), Mai Ndombe Tumba (10), Lomami (9), Garamba (9), Tshopo (9), Salonga (8), Ituri (8), Sankuru (7), Kasai (7), Ubangi Uele (6), Maiko (5), etc. However, the following sites, Kundelungu, Marungu, Kabobo, Itombwe, and Virunga, harbour both endemic and threatened species (Fig. 7).

Nine threatened amphibian species are located on five sites (Upemba Kundelungu, Kabobo, Itombwe, Virunga and Kahuzi-Biega), but most of these $(66.6 \%)$ are found in Itombwe massif (Fig. 8).

Country endemic reptile species with their conservation status

Of the 38 country's endemic reptile species, $12(31.5 \%)$ are found in national parks, but unfortunately, one critically endangered reptile species (Rhampholeon hattinghi Tilbury \& Tolley, 2015, EN) is outside a Protected Areas. The majority $(84.2 \%)$ of endemic reptiles does not have a conservation status but four are listed as DD and two are LC. According to their distribution patterns, the following areas harbour a high number of endemic reptile species (Table 5): Itombwe massif (32), Kahuzi-Virunga (28), Ituri-Tshopo forests (16), Upemba (14), and Lake Tumba-Lake Mai Ndombe (10).

Country's endemic reptile species are distributed on each site as shown in Fig. 9. Most of the country's endemic reptile species are found on the following sites Upemba Kundelungu (12), Virunga (9), Lualaba (9), Kasai (9), Ubangi Uele, KahuziBiega (7), and Itombwe (6).

In this study, a rare species is defined as a restricted range species, which should occur in $27.9 \%$ of all the study sites . Accordingly, we found 159 rare reptile species $(44.41 \%)$, and 13
(3.61\%) widespread species. The following five sites, all situated in the Congo Basin, do not harbour any rare reptile species: Congo River riparian zones, Maiko, Lomami, Sankuru, and Epulu. About the rare amphibian species, there are 128 $(51.8 \%)$ distributed on 25 sites, and $8(3.23 \%)$, are widespread. The following three sites do not harbour any rare amphibian species: Congo River riparian zones, Lomami and Sankuru. All sites of the Albertine Rift ecoregion harbour both rare and widespread species.

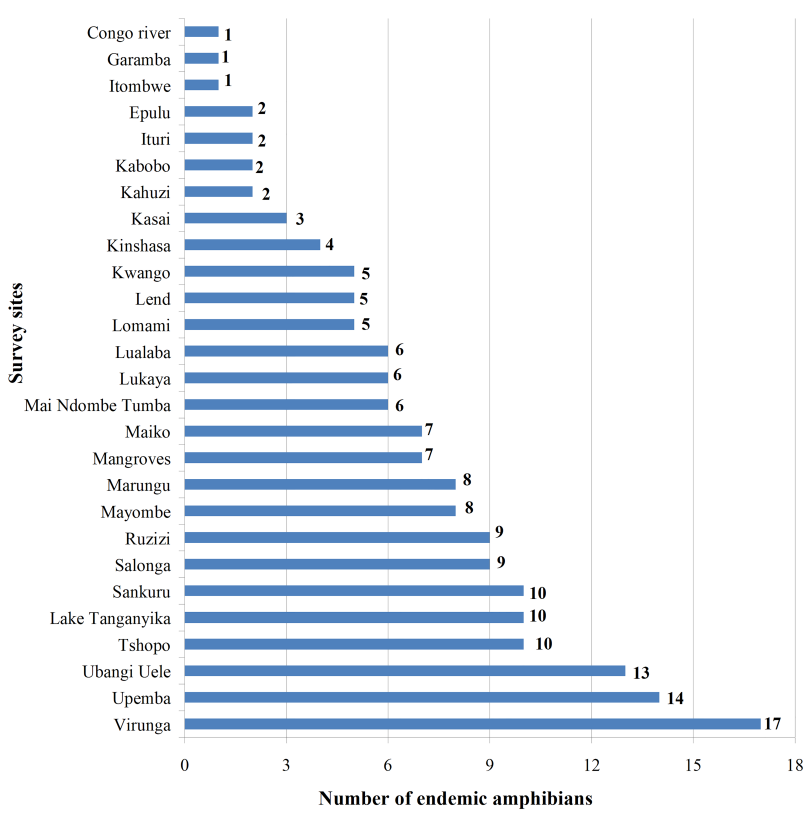

Fig. 7. Distribution of country's endemic amphibian species on the survey sites.

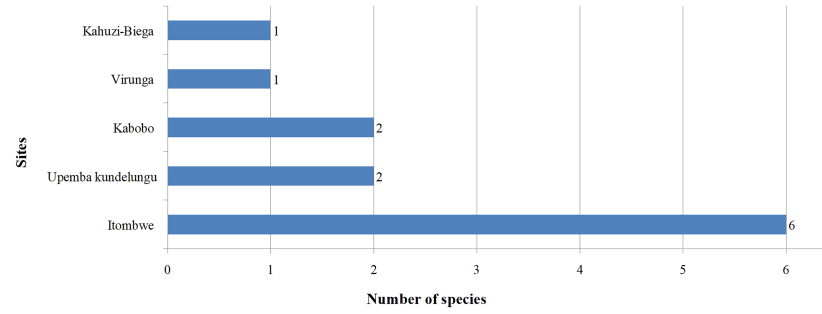

Fig. 8. Distribution of threatened amphibians on survey site.

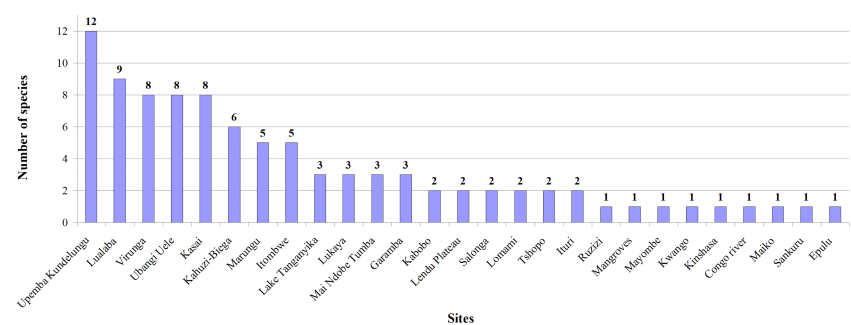

Fig. 9. Distribution of country's endemic reptile species on each site (tags carry out the number of endemic reptile species); tortoises and terrapins from Mangroves and Virunga are the most threatened. 
Table 4. Distribution of country endemic and threatened amphibian species from Democratic Republic of the Congo

\begin{tabular}{|c|c|c|c|}
\hline Country's endemic amphibian species & $\begin{array}{c}\text { Conservation } \\
\text { status categories }\end{array}$ & $\begin{array}{c}\text { Occurrence } \\
\text { in national parks }\end{array}$ & $\begin{array}{c}\text { Occurrence } \\
\text { in nature reserves }\end{array}$ \\
\hline Afrixalus leucostictus Laurent, 1950 & $\mathrm{LC}$ & & Itombwe Kabobo \\
\hline Afrixalus upembae Laurent, 1941 & DD & Upemba & \\
\hline Amietia chapini Noble, 1924 & $\mathrm{NE}$ & Maiko & \\
\hline Arthroleptis hematogaster Laurent, 1954 & DD & & Itombwe, Kabobo \\
\hline Arthroleptis loveridgei De Witte, 1933 & DD & & \\
\hline Arthroleptis phrynoides Laurent, 1976 & DD & & \\
\hline Arthroleptis spinalis Boulenger, 1919 & DD & & \\
\hline Arthroleptis vercammeni Laurent, 1954 & DD & & Itombwe \\
\hline Cacosternum leleupi Laurent, 1950 & DD & Upemba & \\
\hline Callixalus pictus Laurent, 1950 & VU & & Itombwe, Kabobo \\
\hline Cardioglossa congolia Hirschrch, Blackburn, Greenbaum, 2014 & $\mathrm{NE}$ & & \\
\hline Cardioglossa inornata Laurent, 1952 & $\mathrm{NE}$ & & Itombwe, Kabobo \\
\hline Chrysobatrachus cupreonitens Laurent, 1951 & EN & & Itombwe \\
\hline Cryptothylax minutus Laurent, 1976 & DD & & Tumba Leedima \\
\hline Hymenochirus boulengeri De Witte, 1930 & DD & & \\
\hline Hyperolius atrigularis Laurent, 1941 & DD & & \\
\hline Hyperolius chrysogaster Laurent, 1950 & NT & Virunga, Kahuzi-Biega & Itombwe \\
\hline Hyperolius constellatus Laurent, 1951 & VU & & Itombwe \\
\hline Hyperolius diaphanus Laurent, 1972 & DD & & \\
\hline Hyperolius ferrugineus Laurent, 1943 & DD & & \\
\hline Hyperolius ghesquieri Laurent, 1943 & DD & & \\
\hline Hyperolius hutsebauti Laurent, 1956 & DD & Kahuzi-Biega, Virunga & Itombwe, Kabobo \\
\hline Hyperolius inornatus Laurent, 1943 & DD & & Mayombe \\
\hline Hyperolius kibarae Laurent, 1957 & DD & Upemba & \\
\hline Hyperolius leleupi Laurent, 1951 & EN & & Itombwe \\
\hline Hyperolius leucotaenius Laurent, 1950 & EN & & Itombwe \\
\hline Hyperolius obscurus Laurent, 1943 & DD & & \\
\hline Hyperolius polystictus Laurent, 1943 & VU & Kundelungu & \\
\hline Hyperolius pustulifer Laurent, 1940 & DD & & Itombwe \\
\hline Hyperolius robustus Laurent, 1979 & DD & & \\
\hline Hyperolius sankuruensis Laurent, 1979 & DD & & \\
\hline Hyperolius schoutedeni Laurent, 1943 & $\mathrm{LC}$ & & \\
\hline Hyperolius veithi Schik, Kielgast, Röder, Muchai, Burger \& Lötter, 2010 & $\mathrm{NE}$ & Salonga & \\
\hline Hyperolius xenorhinus Laurent, 1972 & DD & Virunga & \\
\hline Kassina mertensi Laurent, 1952 & DD & & \\
\hline Laurentophryne parkeri Laurent, 1950 & DD & & Itombwe \\
\hline Leptopelis anebos Portillo \& Greenbaum, 2014 & $\mathrm{NE}$ & & Itombwe \\
\hline Leptopelis fenestratus Laurent, 1972 & DD & Virunga & \\
\hline Leptopelis lebeaui De Witte, 1933 & DD & Upemba & \\
\hline Leptopelis mtoewaate Portillo \& Greenbaum, 2014 & NE & & Itombwe \\
\hline Leptopelis parvus Schmidt \& Inger, 1959 & DD & Upemba & \\
\hline Mertensophryne schmidti Grandison, 1972 & DD & Upemba & \\
\hline Phrynobatrachus albomarginatus De Witte, 1933 & DD & & \\
\hline Phrynobatrachus anotis Schmidt \& Inger, 1959 & DD & Upemba & \\
\hline Phrynobatrachus asper Laurent, 1951 & DD & & Itombwe \\
\hline Phrynobatrachus bequaerti Barbour \& Loveridge, 1929 & $\mathrm{LC}$ & Kahuzi-Biega, Virunga & \\
\hline Phrynobatrachus congicus Ahl, 1925 & DD & & \\
\hline Phrynobatrachus cryptotis Schmidt \& Inger, 1959 & DD & Upemba & \\
\hline Phrynobatrachus dalcqi Laurent, 1952 & DD & & Ngandja \\
\hline Phrynobatrachus gastoni Barbour \& Loveridge, 1928 & DD & & \\
\hline Phrynobatrachus giorgii De Witte, 1921 & DD & & \\
\hline Phrynobatrachus parkeri De Witte, 1933 & $\mathrm{LC}$ & & \\
\hline Phrynobatrachus scapularis De Witte, 1933 & $\mathrm{LC}$ & Garamba & \\
\hline Ptychadena ingeri Perret, 1991 & DD & Garamba & \\
\hline $\begin{array}{l}\text { Sclerophrys channingi Barej, Schmitz, Menegon, Hillers, Hinkel, } \\
\text { Böhme \& Rödel, } 2011\end{array}$ & $\mathrm{LC}$ & Kahuzi-Biega & Itombwe \\
\hline $\begin{array}{l}\text { Xenopus itombwensis Evans, Carter, Tobias, Kelley, Hanner \& } \\
\text { Tinsley, } 2008\end{array}$ & $\mathrm{CR}$ & & Itombwe \\
\hline $\begin{array}{l}\text { Xenopus lenduensis Evans, Greenbaum, Kusamba, Carter, Tobias, } \\
\text { Mendel \& Kelley, } 2011\end{array}$ & CR & & \\
\hline Total $=57$ & 51 & 19 & 20 \\
\hline
\end{tabular}

Note: VU - Vulnerable, EN - Endangered, CR - Critically Endangered, DD - Data Deficient, LC - Least Concern, NE - Not Evaluated. 
Table 5. List of endemic reptile species with their distribution in the landscapes and their conservation status

\begin{tabular}{|c|c|c|c|}
\hline Endemic reptile species & \begin{tabular}{|c|} 
Conservation \\
status categories \\
\end{tabular} & \begin{tabular}{|c|} 
Occurrence \\
in national parks \\
\end{tabular} & $\begin{array}{c}\text { Occurrence } \\
\text { in nature reserves }\end{array}$ \\
\hline Amblyodipsas rodhaini De Witte, 1930 & DD & & \\
\hline Aparallactus moeruensis De Witte \& Laurent, 1943 & $\mathrm{NE}$ & & \\
\hline Atheris katangensis De Witte, 1953 & $\mathrm{NE}$ & Upemba & \\
\hline Boaedon upembae Laurent, 1954 & $\mathrm{NE}$ & Upemba & \\
\hline Broadleysaurus major Duméril, 1851 & $\mathrm{NE}$ & Garamba & \\
\hline $\begin{array}{l}\text { Congolacerta asukului Greenbaum, Villanueva, Kusamba, Aristote } \\
\text { \& Branch, } 2011\end{array}$ & $\mathrm{NE}$ & & Itombwe \\
\hline $\begin{array}{l}\text { Cordylus marunguensis Greenbaum, Stanley, Kusamba, Moninga, } \\
\text { Goldberg \& Bursey, } 2012\end{array}$ & NE & & \\
\hline Dalophia luluae De Witte \& Laurent, 1942 & $\mathrm{NE}$ & & \\
\hline Gastropholis tropidopholis Boulenger, 1916 & $\mathrm{NE}$ & & \\
\hline Hemidactylus ituriensis Schmidt, 1919 & $\mathrm{NE}$ & & \\
\hline Hypoptophis wilsoni Boulenger, 1908 & $\mathrm{NE}$ & & Sankuru \\
\hline Ichnotropis chapini Schmidt, 1919 & $\mathrm{NE}$ & & \\
\hline Ichnotropis tanganicana Boulenger, 1917 & $\mathrm{NE}$ & & \\
\hline Kinyongia gyrolepis Greenbaum, Tolley, Joma \& Kusamba, 2012 & $\mathrm{NE}$ & & \\
\hline $\begin{array}{l}\text { Kinyongia itombwensis Hughes, Kusamba, Behangana \& } \\
\text { Greenbaum, } 2017\end{array}$ & $\mathrm{NE}$ & & Itombwe \\
\hline Kinyongia mulyai Tilbury \& Tolley, 2015 & $\mathrm{NE}$ & & \\
\hline Leptosiaphos hylophilus Laurent, 1982 & $\mathrm{NE}$ & & \\
\hline Leptosiaphos luberoensis De Witte, 1933 & $\mathrm{NE}$ & Virunga & \\
\hline Leptosiaphos rhodurus Laurent, 1952 & $\mathrm{NE}$ & & Itombwe \\
\hline Letheobia kibarae De Witte, 1953 & $\mathrm{NE}$ & Upemba & \\
\hline Letheobia sudanensis Schmidt, 1923 & $\mathrm{NE}$ & Garamba & \\
\hline Letheobia wittei Roux-Estève, 1974 & $\mathrm{NE}$ & & \\
\hline Mehelya laurenti De Witte 1959 & $\mathrm{NE}$ & & \\
\hline Mehelya wittei Roux-Esteve, 1965 & $\mathrm{NE}$ & Garamba & \\
\hline Monopeltis adercae De Witte, 1953 & $\mathrm{NE}$ & & \\
\hline Monopeltis guentheri Boulenger, 1885 & $\mathrm{NE}$ & & \\
\hline Monopeltis kabindae De Witte \& Laurent, 1942 & $\mathrm{NE}$ & & \\
\hline Monopeltis remaclei De Witte, 1933 & $\mathrm{NE}$ & & \\
\hline Monopeltis scalper Günther, 1876 & $\mathrm{NE}$ & & \\
\hline Monopeltis guentheri Boulenger, 1885 & DD & & \\
\hline Pachydactylus katanganus De Witte, 1953 & $\mathrm{NE}$ & Upemba & \\
\hline Panaspis burgeoni De Witte, 1933 & NE & Virunga & \\
\hline Panaspis helleri Loveridge, 1932 & $\mathrm{LC}$ & Virunga & \\
\hline Pelusios upembae Broadley, 1981 & DD & Upemba & \\
\hline Rhampholeon hattinghi Tilbury \& Tolley, 2015 & $\mathrm{CR}$ & & \\
\hline Trachylepis pulcherima De Witte, 1953 & $\mathrm{NE}$ & Upemba & \\
\hline Trioceros ituriensis Schmidt, 1919 & $\mathrm{LC}$ & & \\
\hline Xenocalamus michellii Müller, 1911 & DD & & \\
\hline Total: & 7 & 12 & 4 \\
\hline
\end{tabular}

Note: NE - Not Evaluated, LC - Least Concern, DD - Data Deficient, CR - Critically Endangered.

Taking into account the criteria presented in Table 6, there were 21 sites, which respond to the SPC determination criteria (red colour). However, the fact that eleven of them (Upemba, Kundelungu, Kahuzi-Biega, Virunga, Salonga, Maiko, Epulu, Garamba, Kinshasa, Mayombe, and Mangroves) were already gazetted as Protected Areas.
The remaining ten unprotected sites (Marungu, Kabobo, Itombwe, Ituri, Tshopo, Ubangi-Uele, Mai Ndombe Tumba, Lukaya, Lualaba, and Sankuru) should be identified as «Sites of Priority for Conservation» and considered as candidates for establishing new Protected Areas in the Democratic Republic of the Congo (Fig. 10). 
Table 6. Sites of priority for conservation determined by ten criteria (ranking procedures are detailed in the Material and Methods)

\begin{tabular}{|c|c|c|c|c|c|c|c|c|c|c|c|c|c|c|c|c|c|}
\hline \multirow{3}{*}{ Sites (n) } & \multicolumn{17}{|c|}{ Criteria } \\
\hline & \multicolumn{2}{|c|}{ S } & \multicolumn{2}{|c|}{$\mathrm{N}$} & \multicolumn{2}{|c|}{$\mathrm{T}$} & \multicolumn{2}{|c|}{$\mathrm{E}$} & \multicolumn{2}{|c|}{$\mathrm{D}\left(\mathrm{S} \_\mathrm{H}\right)$} & \multicolumn{2}{|c|}{ Rares } & \multicolumn{2}{|c|}{ Ir } & \multirow{2}{*}{$\begin{array}{l}\text { Natn } \\
\text { Score }\end{array}$} & \multirow{2}{*}{$\begin{array}{c}\text { Comp } \\
\text { Flagship }\end{array}$} & \multirow{2}{*}{\begin{tabular}{|c|}
$\mathrm{CP}$ \\
Score
\end{tabular}} \\
\hline & A & $\mathrm{R}$ & A & $\mathrm{R}$ & A & $\mathrm{R}$ & $\mathrm{A}$ & $\mathrm{R}$ & A & $\mathrm{R}$ & A & $\mathrm{R}$ & A & $\mathrm{R}$ & & & \\
\hline Congo River (6) & 59 & 107 & 260 & 109 & 2 & 1 & 0 & 2 & 3.565 & 4.078 & 0 & 1 & 0 & 0 & 4 & 0 & 4 \\
\hline Epulu (7) & 97 & 85 & 642 & 108 & 0 & 1 & 0 & 2 & 2.994 & 4.543 & 15 & 1 & 0 & 0 & 4 & Okapia & 3 \\
\hline Garamba (9) & 104 & 103 & 138 & 108 & 0 & 0 & 3 & 3 & 4.465 & 4.644 & 29 & 21 & 0 & 0.7 & 3 & Cerathoterium & 3 \\
\hline Itombwe (8) & 61 & 91 & 518 & 494 & 7 & 0 & 18 & 6 & 3.369 & 4.111 & 30 & 16 & 2.1 & 0 & 5 & Gorilla & 4 \\
\hline Ituri (8) & 72 & 92 & 167 & 92 & 0 & 0 & 6 & 2 & 4.111 & 4.263 & 17 & 19 & 0 & 0.7 & 5 & 0 & 2 \\
\hline Kabobo (7) & 37 & 62 & 618 & 234 & 2 & 0 & 5 & 2 & 2.81 & 3.611 & 8 & 7 & 1.7 & 0 & 5 & Pan & 3 \\
\hline Kahuzi-Biega (11) & 113 & 172 & 429 & 7187 & 1 & 0 & 5 & 7 & 4.139 & 4.663 & 39 & 36 & 0.7 & 1 & 5 & Gorilla & 5 \\
\hline Kasai (7) & 75 & 152 & 805 & 152 & 0 & 0 & 1 & 9 & 2.675 & 4.317 & 13 & 49 & 0 & 0 & 1 & 0 & 1 \\
\hline Kinshasa (7) & 79 & 125 & 218 & 128 & 0 & 1 & 0 & 1 & 3.841 & 4.369 & 18 & 7 & 0 & 0 & 1 & 0 & 1 \\
\hline Kivu basin (2) & 37 & 76 & 226 & 526 & 0 & 0 & 0 & 0 & 2.909 & 3.611 & 8 & 7 & 0 & 0 & 1 & 0 & 1 \\
\hline Kwango (8) & 82 & 117 & 251 & 119 & 0 & 1 & 1 & 1 & 3.895 & 4.382 & 16 & 8 & 0 & 0 & 1 & 0 & 1 \\
\hline Lendu Plateau (5) & 27 & 33 & 212 & 77 & 1 & 0 & 1 & 3 & 1.935 & 3.296 & 6 & 5 & 0 & 0 & 1 & 0 & 1 \\
\hline Lomami (5) & 43 & 102 & 373 & 102 & 0 & 1 & 1 & 3 & 3.328 & 3.664 & 0 & 1 & 0 & 0 & 3 & 0 & 0 \\
\hline Lualaba (7) & 84 & 157 & 137 & 163 & 0 & 0 & 0 & 9 & 4.292 & 4.419 & 17 & 56 & 0 & 0 & 1 & 0 & 0 \\
\hline Lukaya (6) & 59 & 134 & 129 & 136 & 0 & 1 & 0 & 3 & 3.869 & 4.143 & 15 & 16 & 0 & 0 & 1 & 0 & 1 \\
\hline Mai Ndome Tumba (9) & 75 & 128 & 410 & 132 & 0 & 1 & 2 & 3 & 3.318 & 4.317 & 10 & 12 & 0 & 0 & 5 & Pan & 2 \\
\hline Maiko (7) & 55 & 100 & 159 & 100 & 0 & 1 & 1 & 2 & 3.268 & 3.989 & 2 & 2 & 0 & 0 & 5 & Afropavo & 2 \\
\hline Mangroves (10) & 66 & 107 & 135 & 107 & 0 & 5 & 0 & 1 & 3.315 & 4.19 & 19 & 9 & 0 & 4 & 5 & Trichechus & 2 \\
\hline Marungu (5) & 30 & 53 & 83 & 173 & 0 & 0 & 3 & 5 & 3.017 & 3.401 & 8 & 17 & 0 & 1 & 5 & 0 & 1 \\
\hline Mayombe (8) & 63 & 103 & 662 & 107 & 0 & 1 & 1 & 1 & 2.896 & 4.143 & 15 & 6 & 0 & 0 & 4 & 0 & 3 \\
\hline Ruzizi (4) & 35 & 52 & 244 & 359 & 0 & 0 & 0 & 1 & 2.693 & 3.555 & 3 & 4 & 0 & 0 & 1 & Hippopotamus & 0 \\
\hline Salonga Equateur (9) & 60 & 122 & 195 & 132 & 0 & 1 & 1 & 2 & 3.247 & 4.094 & 3 & 9 & 0 & 0 & 5 & Pan & 3 \\
\hline Sankuru6 & 72 & 100 & 417 & 100 & 0 & 0 & 2 & 2 & 3.562 & 4.127 & 0 & 1 & 0 & 0 & 2 & 0 & 0 \\
\hline Tanganyika basin (5) & 48 & 126 & 89 & 837 & 0 & 0 & 1 & 4 & 3.545 & 3.871 & 9 & 18 & 0 & 0 & 2 & 0 & 3 \\
\hline Tshopo (9) & 66 & 115 & 442 & 115 & 0 & 1 & 2 & 3 & 3.139 & 4.19 & 3 & 4 & 0 & 0 & 5 & 0 & 2 \\
\hline Ubangi-Uele (6) & 42 & 119 & 456 & 126 & 0 & 0 & 8 & 8 & 3.218 & 3.738 & 6 & 22 & 0 & 0.7 & 5 & 0 & 1 \\
\hline Upemba-Kundelungu (11) & 122 & 214 & 54988 & 486 & 1 & 0 & 9 & 12 & 2.86 & 4.804 & 50 & 74 & 1.4 & 5 & 5 & Giraffa & 3 \\
\hline Virunga (11) & 100 & 183 & 438 & 1015 & 1 & 1 & 5 & 9 & 3.84 & 4.605 & 37 & 40 & 0.7 & 0.8 & 5 & Gorilla & 4 \\
\hline
\end{tabular}

Note: Captions: A - amphibians, $\mathrm{R}$ - reptiles, $\mathrm{N}$ - number of individual counts or abundances, $\mathrm{S}$ - species richness (threshold of 62 for amphibians and 89 for reptiles), $\mathrm{T}$ - threatened species, $\mathrm{E}$ - endemic species, Com - complementary species, $\mathrm{Rr}-\mathrm{rare}$ species, $\mathrm{Natn}-$ naturalness, $\mathrm{CP}$ - conservation potentials, D (S_H) - Shannon's index, Ir - irreplaceability index.

\section{Discussion}

Today the main conservation issues in the Democratic Republic of the Congo consist of creating new Protected Areas for saving its huge ecosystems and rich biodiversity. Protected Area managers and policy and decision makers are experiencing serious problems due to the lack of ecological baselines for putting in action their conservation intentions. Criteria for designing new Protected Areas do not exist at national level. The already existing Protected Area network include eleven national parks and nature reserves. However, there is an unsolved problem, a high percentage $(65 \%)$ of the whole herpetological diversity is out of the Protected Areas, and human pressure is going fast for destroying habitats and is threatening species. Criteria for creating new Protected Areas should 
be based on scientific information emphasising the key biodiversity areas on national level in compliance with the global standards and IUCN guidelines (Plumptre et al., 2019). The present study, which is the first in the country of this kind, produces the indices that should be used for the identification of priority sites for conservation. A similar study has been recently produced for Uganda (Plumptre et al., 2019). Our results were drawn from long-term and largescale surveys, but the survey efforts were not evenly distributed at the survey sites so that there is need of more inventories in the future. Based on the findings, there are ten SPCs, but it is likely more SPCs will be identified with time when more taxa and habitats are assessed, and when new species are discovered for the country (Greenbaum \& Chifundera, 2012; Greenbaum, 2018). Transect, visual and audition surveys were equally used across the sites, but the quadrat method was used only for surveying burrowing animals hidden in the forest litter. Several herpetologists have used such methodological approach globally. And it cannot negatively affect the results. In fact and as stated in several studies (Heyer et al., 1994; Sutherland, 2000; Dodd, 2010, 2016), a combination of methods would provide quantitative results comparable with other designed studies, and the question about which approach is most appropriate depends on the goals of the comparison.

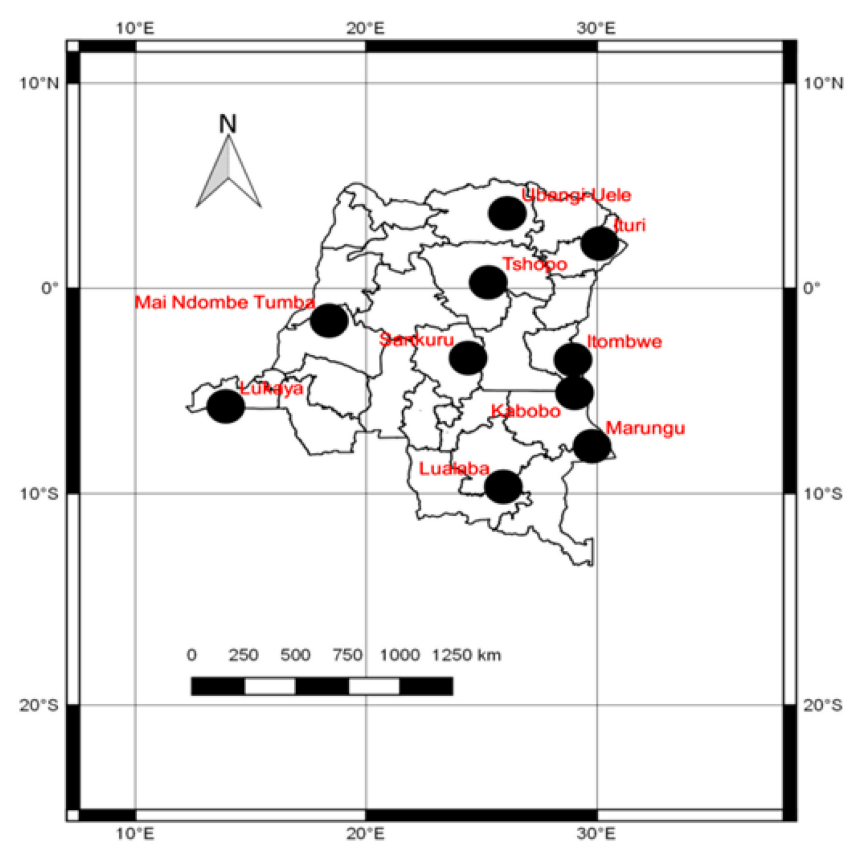

Fig. 10. Geospatial distribution of Sites of Priority for Conservation in the Democratic Republic of the Congo.
Herpetological surveys carried out since 1898 were interested in gathering every specimen for providing, as possible as, more biomaterial for museums located in Europe and the United States (Cael, 2009; Chifundera, 2009). We used historical records to estimate the previous distributions of herpetofauna species, but we know that such records have some limitations and using 100 years old data has been questioned because some specimens were badly preserved in strongly concentrated formalin (Boshoff \& Kerley, 2010). Presently, formalin is not recommended for preserving specimens devoted to taxonomic studies (Greenbaum, 2014). Presently, some museums house voucher specimens that were not useful for this study, and for this reason, we used $25.78 \%$ of the museum records for reliability with quality of species identification and precision of localities. A particular case is that specimens from Upemba National Park and Kahuzi-Biega characterised by high number of amphibian records evaluated for reliability and degree of usefulness, rather than simply elements of abundance. For these reasons, we were obliged to use presence-absence records in order to avoid the influence of abundant sampling sets.

The Democratic Republic of the Congo harbours an important rich herpetological diversity due to the variety of habitats: tropical rainforest in the Congo Basin, montane forests in the Albertine Rift, open dry forests, and the Miombo formation in the Zambezian ecoregions (Porti1 lo et al., 2014, 2018). Based on species richness and endemism we recommend prioritising the Albertine Rift and Lake Mai Ndombe-Lake Tumba landscape. Moreover, the sites of priority for conservation of amphibians and reptiles are located within these two ecoregions. It is generally recognised that the number of reptile species is negatively correlated with latitude and altitude (Dodd, 2010, 2016). This is true in the Democratic Republic of the Congo, too, by comparing the Congo Basin (Central Basin) to the Kivu highlands. However, the centre and the southeast of the Albertine Rift harbour large numbers of species. This can be explained by the fact that from the geological point of view this ecoregion is very old (Tiercellin \& Lezzar, 2003) and the fact that it is the meeting zone of different phytogeographic territories (Robyns, 1948). These findings show two herpetological core areas similar to those of mammals (Hamilton, 1988). The core areas should be considered 
as places where species radiation occurred in the past, and should be explained by the existence of refugia that experienced precipitations on the modern-time scale and relative climate stability (Bell et al., 2017). These refugia are characterised by important species richness and endemism and broadly, the number of species gradually decreases from the refugia to the colonised areas (Zimkus et al., 2017). Consideration of a combination of variables such as species richness, endemism and conservation status, is a central strategy for protecting biological diversity (Scott et al., 1987; Seymour et al., 2001; Sinsch et al., 2011; Anthony et al., 2014; Portillo et al., 2014; Coulombe et al., 2015; Tolley et al., 2016). Consequently, the next studies should be devoted to the assessment of Protected Area effectiveness in conserving the herpetofauna diversity in the Democratic Republic of the Congo (Chape et al., 2005) and collecting more baseline data from unexplored areas. The results from the present study determine ten sites that should be considered as priority sites for conservation because they respond to the fixed criteria. For determining the SPC objective criteria were used, including the species richness, the diversity (combination of species number and abundance), rarity index, the presence of endemic, threatened and complementary species, the irreplaceability the habitat naturalness, and the conservation potentials (Seymour et al., 2001; Brugière, 2012). A score was given to each site and all sites with the scores representing at least $50 \%$ of the used criteria are considered as SPC. Accordingly, there are twenty one sites that responded to the criteria, including already eleven existing Protected Areas. After exclusion of these eleven Protected Areas the following ten sites, Marungu, Kabobo, Itombwe, Ituri, Tshopo, Mai Ndombe-Tumba, Lualaba, Lukaya, Sankuru, and Ubangi-Uele, are qualified «Sites of Priority for Conservation» and proposed new Protected Areas in the Democratic Republic of the Congo.

There are three unprotected sites (Lake Kivu and Lake Tanganyika basins and Ruzizi valley), that are contiguous to Protected Areas, and for this reason they should benefit from this protection effects by extending the Protected Areas or by creating corridors (Burgess et al., 2007). This suggestion responds to the Congolese National Strategy and Action Plan of the Biodiversity that contains guidelines for improving conservation and sustainable use of biodiversity by 2020 . Us- ing law No 14-003 of February 2014, the Congolese Government intends to increase the Protected Area from $11.7 \%$ to $15 \%$ by 2020 (Anonymous, 2014, 2016; UNEP-WCMC, 2016). In fact there is an imperious necessity of creating new and large Protected Areas, new buffer zones for resilience, and where possible, to connect them with large aquatic and terrestrial ecosystems or restore the degraded zones in order to protect the remaining natural areas. But every action to be undertaken must be in accordance with the needs of local human communities that rely on goods, services and money extracted from the ecosystems for their survival.

\section{Conclusions}

At present, the DR Congo hosts 605 herpetofauna species, including 247 amphibian and 358 reptile species. There are five centres of endemism: Kahuzi-Biega-Virunga, Upemba-Marungu, and Itombwe-Kabobo, Lake Tumba-Lake Mai Ndombe, and Ituri-Tshopo forests. There are also two core areas of species radiation: one located in the Albertine and the other in the Congo Basin. Moreover, ten sites that harbour a high species richness and endemism with threatened, rare, and complementary species along high level of conservation potentials, and should be qualified as «sites of priority for conservation». These sites are the proposed «sites of priority for conservation SPC»: Marungu, Kabobo, Itombwe, Ituri, Tshopo, Mai Ndombe-Tumba, Lualaba, Lukaya, Sankuru, and Ubangi-Uele. In total they represent $452261 \mathrm{~km}^{2}$, about $19.1 \%$ of the country area. We therefore encourage the Congolese Wildlife Authority to use these findings for correctly responding to these challenging conservation issues. Additionally, in order to capture most of the biodiversity in one or more sites, it is important to conserve all the sites harbouring complementary species richness. It would allow to a better investment of resources. And by this way conservation and planning strategies may become valuable.

\section{Acknowledgements}

I express my sincere gratitude to the national authorities at the Institut Congolais pour la Conservation de la Nature (ICCN, Kinshasa) and the Centre de Recherche en Sciences Naturelles (CRSN, Lwiro) for providing research permits and laboratory facilities. Part of this work was funded by a grant from NGS offered in collaboration with $\mathrm{PhD}$ Eli Greenbaum (University of Texas at El Paso, UTEP, USA). I am very thankful to 
PhD Danny Meirte (Royal Museum for Central Africa, Belgium), PhD Zoltan T. Nagy and Erik Verheyen (Royal Institute of Natural Sciences of Belgium) for relevant training in taxonomic studies. My fieldwork assistants, namely Luhumyo Mutwa Maurice and Mastaki Muninga Wandege are warmly acknowledged.

\section{Supporting Information}

The full dataset with 358 reptile species (Electronic Supplement 1: List of studied reptile species from the Democratic Republic of the Congo), and 247 amphibian species (Electronic Supplement 2: List of studied amphibian species from the Democratic Republic of the Congo) may be found in the Supporting Information here.

\section{References}

Anonymous. 2014. Loi relative à la conservation de la $\mathrm{Na}$ ture en RD Congo. Kinshasa: Gouvernement Congolais. 27 p.

Anonymous. 2016. Stratégie et plan d'action nationaux de la biodiversité (2016-2020). Kinshasa: Ministère de l'Environnement Conservation de la Nature et Développement Durable du Gouvernement Congolais. 91 p.

Anthony N.M., Atteke C., Bruford M.W., Dallmeier F., Freedman A., Hardy O., Ibrahim B., Jeffery K.J., Johnson M., Lahm S.A., Lepengue N., Lowenstein J.H., Maisels F., Mboumba J.-F., Mickala P., Morgan K., Ntie S., Smith T.B., Sullivan J.P., Verheyen E., Gonder M.K. 2014. Evolution and Conservation of Central African Biodiversity: Priorities for Future Research and Education in the Congo Basin and Gulf of Guinea. Biotropica 47(1): 6-17. DOI: 10.1111/btp.12188

Baillie J.E.M., Hilton-Taylor C., Stuart S.N. 2004. IUCN Red List of Threatened Species. A global assessment. Cambridge (UK): The Red List Consortium. IUCN Red List Programme Office. $191 \mathrm{p}$.

Behangana M., Kasoma P.M.B., Luiselli L. 2009. Ecological correlates of species richness and population abundance patterns in the amphibian communities from the Albertine Rift, East Africa. Biodiversity and Conservation 18(11): 2855-2873. DOI: $10.1007 /$ s10531-009-9611-9

Bell R.C., Parra J.L., Badjedjea G., Barej M.F., Blackburn D.C., Burger M., Channing A., Dehling J.M., Greenbaum E., Gvozdik V., Kielgast J., Chifundera K., Lotters S., McLaughlin P.J., Nagy T.Z., Rodel M.-O., Portik D.M., Stuart B.L., Vanderwal J., Zassi-Boulo A.G., Zamudio K.R. 2017. Idiosyncratic responses to climatedriven forest fragmentation and marine incursions in reed frogs from Central Africa and the Gulf of Guinea Islands. Molecular Ecology 26(19): 5223-5244. DOI: 10.1111/mec. 14260

Blaxter M., Mann J., Chapman T., Thomas F. Whitton C., Floyd R., Abebe E._2005. Defining operational taxonomic units using DNA barcode data. Philosophical Transactions of the Royal Society of London B. Biological Sciences 360(1462): 1935-1943. DOI: 10.1098/ rstb.2005.1725
Bloom S.A. 1981. Similarity indices in community studies: Potential Pitfalls. Marine Ecology Progress Series 5(2): 125-128. DOI: 10.3354/meps005125

Bourgeois M. 1968. Contribution a la morphologie compare du crane des ophidiens de l'Afrique Centrale. Publications de l'Université Officielle du Congo (Lubumbashi). Vol. 18. Lubumbashi: Université Officielle du Congo. 293 p.

Bray J.R., Curtis J.T. 1957. An ordination of upland forest communities of southern Wisconsin. Ecological Monographs 27(4): 325-349. DOI: 10.2307/1942268

Broadley D.G., Tolley K.A., Conradie W., Wishart S., Trape J.-F., Burger M., Kusamba C., Zassi-Boulou A.-G., Greenbaum E. 2018. A phylogeny and genus-level revision of the African File Snakes Gonionotophis Boulenger (Squamata: Lamprophiidae). African Journal Herpetology 67(1): 43-60. DOI: 10.1080/21564574.2018.1423578

Brugière D. 2012. Indentifying priority areas for the conservation of antelopes in the Republic of Guinea, West Africa, and using complementary approach. Oryx 46(2): 253-259. DOI: 10.1017/S0030605311000391

Burgess N.D., Loucks C., Stolton S., Dudley N. 2007. The potential of forest reserves for augmenting the protected area network in Africa. Oryx 41(2): 151-159. DOI: 10.1017/S0030605307001895

Chape S., Harrisson J., Spalding M., Lysenko I. 2005. Measuring the extent and effectiveness of protected areas as an indicator for meeting global biodiversity targets. Philosophical Transactions of the Royal Society B (Biological Sciences) 360(1454): 443-455. DOI: 10.1098/rstb.2004.1592

Chen W., Zhang C.K., Cheng Y., Zhang S., Zhao H. 2013. A comparison of methods for clustering $16 \mathrm{~S}$ rRNA sequences into OTUs. PLoS ONE 8(8): e70837. DOI: 10.1371/journal.pone.0070837

Chifundera K., Nagy T.Z., Greenbaum E., Kielgast J., Gvozdik V., Konrad M. 2014. L'herpetofaune de la Cuvette Centrale en RD Congo. In: E. Verheyen (Ed): Proceedings of the First International Conference on the Congo Basin. Kisangani: Congo Biodiversity Initiative, Centre de Surveillance de la Biodiversité (CSB). P. 95-96.

Chifundera K., Behangana M. 2013. Status of amphibians and reptiles in the AR and priorities for conservation. In: S. Kanyamibwa (Ed.): Albertine Rift conservation status report. Albertine Rift Conservation Series 1. ARCOS network. P. 46-50.

Chifundera K. 2012. Commerce illicite de la viande de brousse en zones de conflits armés à l'Est de la République Démocratique du Congo et son impact sur la biodiversité. Mémoire DEA. Kinshasa: UPN. 109 p.

Chifundera K. 2009. Amphibian and reptile collections at the Royal Museum for Central Africa with a focus on bibliographical references as an appraisal for further studies. Tervuren (Belgium): Scientific Report, UNESCO-MA with Congo 2010 Consortium \& the Royal Museum for Central Africa. 36 p.

Chifundera K. 1990. Snakes of Zaire and their bites. African Study Monographs 10(3): 137-158. 
Chifundera K., Malasi N.D. 1989. La connaissance des ophidiens dans le Bulega (Kivu, Est du Zaïre). African Study Monographs 10(1): 39-48.

Coulombe D., Nadeau S., Ouellet J.-F. 2015. Milieux naturels prioritaires pour la conservation de la biodiversité: territoire privé du Bas-Saint-Laurent. Rimouski: Agence régionale de mise en valeur des forêts privées du Bas-Saint-Laurent. 93 p.

De Witte G.F. 1966. Reptiles. Exploration du Parc National de Garamba. Mission de Saeger 48: 1-108.

De Witte G.F. 1965. Les caméléons de l'Afrique Centrale. Annales du Musée Royal du Congo Belge Tervuren (Belgique): Serie in- $8^{\circ}$ - Sciences Zoologiques 142: 1-215.

De Witte G.F. 1962. Genera des serpents du Congo et du Ruanda-Urundi. Annales du Musée Royal du Congo Belge Tervuren (Belgique): Serie in- $8^{\circ}$ - Sciences Zoologiques 104: 1-203.

Dodd R. 2018. Reptile Presence or Likely Absence Survey Report. Townhill, Swansea: WWE18045 RS Rev B. ISSUING OFFICE Britannia House Caerphilly Business Park Van Road CAERPHILLY CF83 3GG.POBL Group / UWTSD. P. 1-25

Dodd Jr.C.K. 2016. Reptile Ecology and Conservation. A Handbook of Techniques. Oxford: Oxford University Press. P. 462.

Dodd Jr.C.K. 2010. Amphibian Ecology and Conservation. Oxford: Oxford University Press. 556 p.

Dirzo R., Young H.S., Galetti M., Ceballos G., Isaac N.J., Collen B. 2014. Defaunation in the Anthropocene. Science 345(6195): 401-406. DOI: 10.1126/ science. 1251817

Eeckout X. 2010. Sampling amphibians and reptiles. In: J. Eymann, J. Degreef, C. Häuser, J.C. Monje, Y. Samyn, D. VandenSpiegel (Eds.): Manual on field Recording techniques and protocols for All Taxa Biodiversity Inventories and Monitoring. Vol. 8. Brussels: Abc Taxa. P. 530-557.

Erdős L., Bátori Z., Penksza K., Tölgyesi C. 2017. Can Naturalness Indicator Values Reveal Habitat Degradation? A Test of Four Methodological Approaches. Polish Journal of Ecology 65(1): 1-13. DOI: 10.3161/15052249PJ E2017.65.1.001

Evans B.J., Greenbaum E., Chifundera K., Carter T.F., Tobias M.L., Mendel S.A., Kelley D.B. 2011. Description of a new octoploid frog species (Anura: Pipidae: Xenopus) from the Democratic Republic of the Congo, with a discussion of the biogeography of African clawed frogs in the Albertine Rift. Journal of Zoology 283(4): 276-290. DOI: 10.1111/j.14697998.2010.00769.x

Frost D.R. 2018. Amphibian Species of the World: an Online Reference. Version 6.0. Electronic Database. New York, USA: American Museum of Natural History. Available from http://research.amnh.org/herpetology/amphibia/index.html

Gormley A.M., Forsyth D.M., Griffioen P., Lindeman M., Ramsey D.S.L., Scroggie M.P., Woodford L. 2011. Using presence-only and presence-absence data to estimate the current and potential distributions of established invasive species. Journal of Applied Ecology 48(1): 25-34. DOI: 10.1111/j.13652664.2010.01911.x

Greenbaum E. 2017. Emerald Labyrinth: A Scientist's Adventures in the Jungles of the Congo. Lebanon, New Hampshire: ForeEdge. 336 p.

Greenbaum E., Chifundera K. 2012. Conservation Implications Following the Rediscovery of Four Frog Species from the Itombwe Natural Reserve, Eastern Democratic Republic of the Congo. Herpetological Review 43(2): 253-259.

Gutiérrez-Hernández O., Sánchez M.E., Ramo C., Sánchez-Solana J.E., García L. 2017. The occurrence of Phytophthora cinnamomi in southern Spain: Presence - absence records and potential distribution area. Integrated Protection in Oak Forests IOBC-WPRS Bulletin 12: 105-109.

Hamilton A.C. 1988. Guenon evolution and forest history. In: A. Gautier-Hion (Eds.): A Primates radiation: evolution of biology of the African guenons. Oxford: Oxford University Press. P. 16-33

Hammer O., Harper D.A.T., Ryand P.D. 2001. PAST: Paleontological statistics package for education and data analysis. Palaeontologica Electronica 4(1): 1-9.

Hartley A.J., Nelson A., Mayaux P., Gregoire J.-M. 2007. The assessment of African Protected areas. Ispra Italy: JRC-IES. 230 p.

Hedges S.B. 2014. The high-level classification of skinks (Reptilia, Squamata, Scincomorpha)._Zootaxa 3765(4): 317-338. DOI: 10.11646/zootaxa.3765.4.2

Heyer R., Donnelly A.M., McDiarmid R.W., Hayek L.-A., Foster M.S. 1994. Measuring and monitoring biological diversity. Standard methods for amphibians. In: S. Mercedes Foster (Ed.): Biological Biodiversity Handbook Series. Washington and London: Smithsonian Institution. 364 p.

Heymans J.C. 1982. Contribution a la phylogenèse des ophidiens de l'Afrique Centrale. Annales de la Société Royale de Zoologie de Belgique 112(1): 79-87.

Hughes F.D., Tolley A.K., Behangana M., Lukwago W., Menegon M., Dehling JM., Stipala J., Tilbury R.C., Khana M.A., Chifundera K., Greenbaum E. 2018. Cryptic diversity in Rhampholeon boulengeri (Sauria: Chamaeleonidae), a pygmy chameleon from the Albertine Rift biodiversity hotspot. Molecular Phylogenetics and Evolution 122: 125-141. DOI: 10.1016/j.ympev.2017.11.015

Hughes F.D., Chifundera K., Behangana M., Greenbaum E. 2017. Integrative taxonomy of the Central African forest chameleon, Kinyongia adolfifriderici (Sauria: Chamaeleonidae), reveals underestimated species diversity in the Albertine Rift. Zoological Journal of the Linnean Society 181(2): 400-438. DOI: 10.1093/zoolinnean/zlx005

IUCN. 2017. The IUCN red list of threatened species, version 2017-2. Available from www.iucnredlist.org

Jenkins C.N., Pimm S.L., Joppa L.N. 2013. Global patterns of terrestrial vertebrate diversity and conservation. Pro- 
ceedings of the National Academy of Sciences 110(28): E2602-E2610. DOI: 10.1073/pnas. 1302251110

Kielgast J., Lötters S. 2011. The green heart of Africa is a blind spot in herpetology. FrogLog 97: 16-17.

Larson T.R., Castro D., Behangana M., Greenbaum E. 2016. Evolutionary history of the River frog genus Amietia (Anura: Pyxicephalide) reveals extensive diversification in Central Africa. Molecular Phylogenetics and Evolution 199: 168-181. DOI: 10.1016/j. ympev.2016.03.017

Laurent R.F. 1983. About the herpetofauna of Central African montane forest. In: A. Rhodin, K. Miyata (Eds.): Advances in Herpetology and Evolutionary Biology. Cambridge: Museum of Comparative Zoology Harvard University. P. 350-358.

Laurent R.F. 1982. Le genre Afrixalus Laurent (Hyperoliidae) en Afrique Centrale. Musée Royal de l'Afrique Centrale, Tervuren, Belgique: Annales - Serie in $8^{\circ}$ Sciences Zoologiques 235: 1-58.

Laurent R.F. 1973. A parallel survey of Equatorial amphibians and reptiles in Africa and South America. In: B.J. Meggers, E.S. Ayensu, W.D. Duckworth (Eds.): Tropical Forest Ecosystems in Africa and South America: a Comparative Review. Washington: Smithsonian Institution Press. P. 259-266.

Laurent R.F. 1972. Amphibiens. Exploration du Parc National des Virunga, 2 è série, Fasc. 22. Bruxelles: Fondation pour favoriser les recherches scientifiques en Afrique. P. 1-125.

Laurent R.F. 1965. Contribution à l'histoire de l'herpétologie congolaise et bibliographie générale. Mémoires de l'Académie Royale des Sciences d'Outre-mer (ORSOM) 16: 1-200.

Laurent R.F. 1956. Contribution à l'herpétologie de la Région des Grands Lacs de l'Afrique Centrale. Annales du Musée Royal du Congo Belge Tervuren (Belgique): Serie in- $8^{\circ}$ - Sciences Zoologiques 48: 1-390.

Magurran A.E., McGill B.J. 2011. Biological Diversity. Frontiers in measurement and assessment. Oxford: Oxford University Press. 337 p.

Matthyssen S. 2014. Biodiversity assessment of snakes in the Democratic Republic of the Congo by means of DNA barcoding. MSc Thesis. Antwerpen: University of Antwerpen. $100 \mathrm{p}$.

Mbalanda P.K. 2006. Recueil des textes juridiques en matière environnementale en République Démocratique du Congo. Kinshasa: Advocats Verts. 569 p.

Milian J., Rodary E. 2010. La conservation de la biodiversité par les outils de priorisation Entre souci d'efficacité écologique et marchandisation. Revue Tiers Monde 202: $36-56$.

Mubalama K.L. 2010. Monitoring law enforcement effort and illegal activity in selected protected areas: implications for management and conservation. $\mathrm{PhD}$ Thesis. Belgium: University of Ghent. 348 p.

Nagy T.Z. 2014. Assessing the diversity of Congolese snakes with DNA barcoding. In: E. Verheyen (Ed.): Proceedings of the First International Conference on the Congo Basin. Kisangani: Congo Biodiversity Initiative, CSB. 105 p.
Nagy T.Z., Chifundera K., Collet M., Gvoždík V. 2013. Notes on the herpetofauna of western Bas-Congo, Democratic Republic of the Congo. Herpetology Notes 6(1): 413-419.

Plumptre A.J., Ayebare S., Behangana M., Forrest T.G., Hatanga P., Kabuye C., Kirunda B., Kityo R., Mugabe H., Namagana M., Nampindo S., Nangendo G., Nkuutu D.N., Pomeroy D., Tushabe H., Prinsloo S. 2019. Conservation of vertebrates and plants in Uganda: Identifying Key Biodiversity Areas and other sites of national importance. Conservation Science and Practice 1(2): e7. DOI: $10.1002 / \operatorname{csp} 2.7$

Portillo F., Branch W.R., Conradie W., Rödel M.-O., Penner J., Michael G., Barej F., Chifundera K., Muninga M.W., Aristote M.M., Bauer A.M., Trape J.-F., Nagy T.Z., Carlino P. , Pauwels S.G.O., Menegon M., Burger M., Mazuch T., Jackson K., Hughes F.D., Behangana M., Greenbaum E. 2018. Phylogeny and biogeography of the African burrowing snake subfamily Aparallactinae (Squamata: Lamprophiidae). Molecular Phylogenetics and Evolution 127: 288-303. DOI: 10.1016/j.ympev.2018.03.019

Portillo F., Greenbaum E., Menegon M., Chifundera K., Dehling J.M. 2014. Phylogeography and species boundaries of Leptopelis (Anura: Arthroleptidae) from the Albertine Rift. Molecular Phylogenetics and Evolution 82(A): 75-86. DOI: 10.1016/j. ympev.2014.09.024

Pyron R.A., Burbrink F.T., Wiens J.J. 2013. A phylogeny and revised classification of Squamata, including 4161 species of lizards and snakes. BMC Evolutionary Biology 13(1): 93. DOI: 10.1186/1471-2148-13-93

Robyns W. 1948. Les Territoires Phytogéographiques du Congo Belge et du Ruanda-Urundi. Bruxelles: Atlas Général du Congo Belge. Bruxelles: Institut Royal Colonial Belge. $10 \mathrm{p}$.

Roelke C.E., Greenbaum E., Chifundera K., Aristote M.M., Smith E.N. 2011. Systematics and conservation status of two distinct Albertine Rift tree frogs, Leptopelis karissimbensis and L. kivuensis (Anura: Arthroleptidae). Journal of Herpetology 45(3): 343351. DOI: 10.1670/10-092.1

Roux-Estève R. 1974. Recherche sur la morphologie, la biogéographie et la phylogénie des Typhlopidae d'Afrique. Bulletin de l'Institut Fondamental de l'Afrique Noire, ser. A. 36: 428-508.

Schmidt K.P., Noble G.K. 1998. Contribution to the Herpetology of the Belgian Congo. Ithaca, New York: Society for the Study of Amphibians and Reptiles \& Herpetological Association of Africa. 348 p.

Scott J.M., Csuri B., Jacobi J.D., Estes J.E. 1987. Species richness. A geographic approach to protecting future biological diversity. BioScience 37(11): 782-788.

Seymour C.L., De Klerk H.M., Channing A., Crowe T.M. 2001. The biogeography of the Anura of sub-equatorial Africa and the prioritization of areas for their conservation. Biodiversity and Conservation 10(12): 20452076. DOI: 10.1023/A:1013137409896

Sinsch U., Greenbaum E., Kusamba C., Lehr E. 2011. Rapid assessment of montane anuran communities in the Al- 
bertine Rift: Hyperolius castaneus Ahl, 1931 as a focal species for conservation. African Zoology 46(2): 320 333. DOI: 10.1080/15627020.2011.11407505

Smith P.G.R., Theberge J.B.A. 1986. Review of Criteria for Evaluating Natural Areas. Environmental Management 10(6): 715-734. DOI: DOI: 10.1007/BF01867726

Sokal R.R., Sneath H.A.1963. Principles of Numerical Taxonomy, San Francisco: W.H. Freeman. 359 p.

Somerfield P.J. 2008. Identification of Bray-Curtis similarity index: comment on Yoshioka (2008). $M a$ rine Ecology Progress Series 372: 303-306. DOI: 10.3354/meps07841

Speight M.C.D. 1992. Distribution data, threat categories and site evaluation. In: J.L. van Goethem \& P. Grootaert (Eds.): Proceedings of the $8^{\text {th }}$ International Colloquium of the European Invertebrates Survey "Faunal inventories of sites for cartography and conservation”. Brussels. P. 24.

TDWG. 2017. Taxonomic Database Working Group. Biodiversity information Standards. Brussels. Available from https://www.tdwg.org/

Thys van Den Audaenerde D.F.E. 1963a. Les Agamidae $\mathrm{du}$ Congo: les espèces et leur distribution géographique. Revue de Zoologie et Botanique Africaines 68: 203-250.

Thys van Den Audaenerde D.F.E. 1963b. Les gekkonidae de l'Afrique centrale. Revue Zoologie et Botanique Africaines. 76: 163-172.

Thomson S.A., Pyle R.L., Ahyong S.T., Alonso-Zarazaga M., Amirati J., Araya J.F., Ascher J.S., Audisio T.L., Azevedo-Santos V.M., Bailly N., Baker W.J., Balke M., Barclay M.V.L., Barrett R.L., Benine R.C., Bickerstaff J.R.M., Bouchard P., Bour R., Bourgoin T., Boyko C.B., et al. 2018. Taxonomy based on science is necessary for global conservation. PLoS Biology 16(3): e2005075. DOI: 10.1371/journal.pbio.20055075.

Tolley A.K., Alexander J.G., Branch R.W., Bowles P., Maritz B. 2016.Conservation status and threats for African reptiles. Conservation Biology 204(A): 63-71. DOI: 10.1016/j.biocon.2016.04.006

Townsend T.M., Larson A., Louis E., Macey J.R. 2004. Molecular phylogenetics of Squamata: The position of snakes, amphisbaenians, and dibamids, and the root of the Squamata tree. Systematic Biology 53(5): 735-757. DOI: $10.1080 / 10635150490522340$

Uetz P., Hošek J. 2018. The Reptile Database. Available from http://www.reptile-database.org.

Uetz P. 2010. The original descriptions of reptiles. Zootaxa 2334: 59-68. DOI: 10.11646/zootaxa.2334.1.3

UNEP-WCMC. 2016. Global statistics from the World Database on Protected Areas (WDPA). Cambridge:
IUCN, Gland Switzerland. World Database on Protected Areas (WDPA).

Valencia-Aguilar A., Cortés-Gómez A.M., Ruiz-Agudelo C.A. 2013. Ecosystem services provided by amphibians and reptiles in Neotropical ecosystems. International Journal of Biodiversity Science, Ecosystem Services and Management 9(3): 257-272. DOI: 10.1080/21513732.2013.821168

Van Oudenhoven A.P.E., de Groot R.S. 2013. Ecosystem services assessments to improve management of marine habitats, amphibians and reptiles, forest biodiversity and silviculture, and medicinal plants. International Journal of Biodiversity Science, Ecosystem Services and Management 9(3):181-184. DOI: 10.1080/21513732.2013.827882

Vidal N., Hedges S.B. 2005. The phylogeny of Squamata reptiles (lizards, snakes, and amphisbaenians) inferred from nine nuclear protein-coding genes. Comptes Rendus Biologies 328(10-11): 1000-1008. DOI: 10.1016/j.crvi.2005.10.001

Vitule J.R.S., Freire C.A., Vazquez D.P., Nunez M.A., Simberloff D. 2012. Revisiting the Potential Conservation Value of Non-Native Species. Conservation Biology 26(6): 1153-1155. DOI: 10.1111/j.1523-1739.2012.01950

Wüster W., Chirio L., Trape J.-F., Ineich I., Jackson K., Greenbaum E., Barron C., Kusamba C., Nagy Z.T., Storey R., Hall C., Wüster C.E., Barlow A., Broadley D.G. 2018. Integration of nuclear and mitochondrial gene sequences and morphology reveals unexpected diversity in the forest cobra (Naja melanoleuca) species complex in Central and West Africa (Serpentes: Elapidae). Zootaxa 4455(1): 68-98. DOI: 10.11646/ zootaxa.4455.1.3

Yoshioka P.M. 2008. Misidentification of the Bray-Curtis similarity index. Marine Ecology Progress Series 368: 309-310. DOI: 10.3354/meps07728

Zimkus B.M., Lawson L.P, Barej M., Barratt C.D., Channing A., Dash K.M., Dehling J.M., Du Preez L., Gehring P.S., Greenbaum E., Gvozdik V., Harvey J., Kielgast J., Chifundera K., Nagy T. Z., Pabijan M., Penner J., Rödel M.-O, Vences M., Lötters S. 2017. Leapfrogging into new territory: How Mascarene ridged frogs diversified across Africa and Madagascar to maintain their ecological niche. Molecular Phylogenetics and Evolution 106: 254-269. DOI: 10.1016/j.ympev.2016.09.018

Zhuravleva I., Turubanova S., Potapov P., Hansen M., Tyukavina A., Minnemeyer S., Laporte N., Goetz S., Verbelen F., Thies C. 2013. Satellite-based primary forest degradation assessment in the Democratic Republic of the Congo, 2000-2010. Environmental Research Letters. 8(2): 024034. DOI: 10.1088/1748-9326/8/2/024034 


\title{
ИСПОЛЬЗОВАНИЕ ИНДЕКСОВ РАЗНООБРАЗИЯ ДЛЯ ИДЕНТИФИКАЦИИ УЧАСТКОВ, ПРИОРИТЕТНЫХ ДЛЯ СОХРАНЕНИЯ ГЕРПЕТОФАУНЫ В ДЕМОКРАТИЧЕСКОЙ РЕСПУБЛИКЕ КОНГО
}

\author{
К. 3. Чифундера ${ }^{1,2}$ \\ ${ }^{1}$ Исследовательский центр естественных наук Лвиро, Демократическая Республика Конго \\ ${ }^{2}$ Наииональный педагогический университет Киншасы, Демократическая Республика Конго \\ e-mail:chifkusamba@gmail.com
}

\begin{abstract}
На сегодняшний день знания о герпетологическом разнообразии и распространении видов в Демократической Республике Конго остаются в основном неполными. Чтобы восполнить этот пробел, мы провели долгосрочные и широкомасштабные герпетологические обследования для улучшения изученности встречаемости представителей герпетофауны и видового состава. Сканирование участков, визуальное обследование, методы трансект и учетных площадей совместно с записями голосов использовались для определения видов и выявления местонахождения амфибий на каждом участке обследования. Дополнительные данные были получены из литературных обзоров и музейных коллекций. Герпетологическое разнообразие было оценено на 28 участках, расположенных в экорегионах бассейна p. Конго и рифта Альбертин. Все обследованные местонахождения и участки были привязаны к географическим координатам для создания карт распространения видов с использованием программного обеспечения QGIS 2.14.0. Индексы герпетологического разнообразия были рассчитаны с помощью программного обеспечения PAST. Используя морфологические признаки и данные анализа ДНК, мы составили списки видов на местном и национальном уровнях. Результаты показывают, что богатая конголезская герпетофауна включает 605 видов, в том числе 247 (40.83\%) земноводных и $358(59.17 \%)$ рептилий. Было зарегистрировано 57 видов эндемичных амфибий (23.1\% от общего числа видов), из которых 19 видов (32.7\%) расположены на особо охраняемых природных территориях. Было отмечено 38 видов эндемичных рептилий (10.6\% от общего числа видов), из которых 12 (31.5\%) было зарегистрировано на особо охраняемых природных территориях. Кроме того, отмечено девять и семнадцать угрожаемых видов амфибий и рептилий, соответственно. Но только $20 \%$ из них были обнаружены в пределах национальных парков. Представляется вполне вероятным, что, если не будут предприняты какие-либо меры противодействия влиянию человека на среду обитания, в Демократической Республике Конго произойдет сокращение количества популяций и видов. На основании соответствующих индексов, включая видовое богатство, редкость, разнообразие, эндемизм, присутствие угрожаемых видов и других объективных критериев, основанных на международных стандартах, следующие десять участков были определены как приоритетные для охраны: Марунгу, Кабобо, Итомбве, Итури, Тшопо, Маи Ндомбе Тумба, Луалаба, Лукая, Санкуру и Убанги Уэле. Эти участки предлагаются в качестве новых особо охраняемых природных территорий для достижения правительственных национальных природоохранных целей по сохранению земель, необходимых для сохранения богатого биоразнообразия.
\end{abstract}

Ключевые слова: видовое богатство, географическое распространение, исследования земноводных и рептилий, особо охраняемая природная территория, угрожаемый вид, Центральная Африка, эндемичный вид 